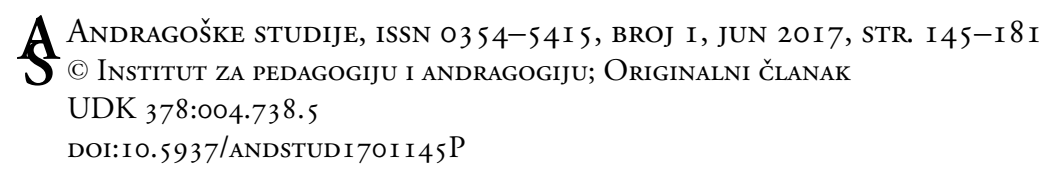

Pankász Balázs ${ }^{1}$

University of Pécs, Hungary

\title{
Online Educational Environments and ICT Tools in Higher Education: Teacher Survey
}

\begin{abstract}
The role of the Internet and digital tools in higher education are incontestable at the beginning of the $21^{\text {st }}$ century. The technological development creates quick changes in this area. Due to the globalized environment and the innovations in IT, the participants of the educational system have to face new challenges. New questions and problems are appearing that need to be solved. How do the changes of technological opportunities and needs transform higher education? Is it possible to use web 2.0 applications for education? How and to what extent should digital tools be inserted into education? The paper and the related research attempt to discover the the opinion of teachers and students about web 2.0 Web 2.0 applications' learning / teaching purposes. Could these tools be used in education to contribute to individual and collective knowledge building? Scientific studies show that students' habits of using Internet are not homogenous. Teachers require different attributes, they need a different kind of higher education. The survey also seeks to discover what the real differences are between different generations' attitudes toward learning and Internet usage.
\end{abstract}

Keywords: higher education, web 2.0, learning theories.

\section{Purpose}

The importance of the Internet and digital tools in higher education is unquestionable at the beginning of the $21^{\text {st }}$ century. The technological development of the globalized world is creating fast changes in this area; due to IT innovations the actors of the educational system have to face new challenges. With these changes new questions and problems are raised. How do technological opportunities and

\footnotetext{
${ }^{1}$ Dr Pankász Balázs is Assistant Professor at University of Pécs, Faculty of Cultural Sciences, Education and
} Regional Development in Hugary (pankasz.balazs@kpvk.pte.hu). 
demands transform higher education and is it possible to use social networks and web 2.0 applications in education? How and to what extent should digital tools be built into education? What new competences do teachers and students need to continue the digital development?

Higher education is trying to keep up with technological development by building new tools into its practice. This survey is exploring online environments of higher education, and attempting to unfold the opinions of professors and students about using new and popular digital opportunities in education for teaching and learning. Is it really possible to use these tools in education and will they help personal and collective learning? The research is also trying to find out how web 2.0 applications affect learning and if network based learning and e-learning are really efficient tools in higher education.

The Internet has an important place of social life, the number of users are increasing, and web 2.0 programs are still very popular (Ujhelyi, 2011). The technological revolution affects every part of life, and it also transforms the way we learn. The technological developments have an influence on social progression by modifying and shaping everyday practices of communication, obtaining information, free time and learning as well (Sipos, Varga \& Egervári, 2015). The spreading of the Internet and the popularity of web 2.0 applications together with the network based learning theories create the possibility of online and interactive courses (Forgó, 2015). The online educational environment is a compound and holistic phrase that involves learning methods, technological tools and learning and pedagogical paradigms as well (Papp-Danka, 2014).

Education's process of finding new ways and frames is relevant in the knowledge based society. As the social and economic environments are changing, cultural, motivational, communicational and social differences, attitudes and demands of students in higher education are getting more visible. Because of the technological innovations, changes are hard to follow and in the meantime theories in connection with learning and obtaining information are broadening. The fast development of IT in the previous decades has affected higher education and has deeply transformed the learning environment. This implies the presence of new possibilities and challenges and affects the spreading of e-learning in a positive way. "E-learning is an educational activity, which uses electric technology or tools" (Kovács, 2011), including learning with the use of computers or the opportunities of online educational network as well. According to the wildest theory, e-learning is "every act of learning that happens through the use of tools of information and communication. "It helps the development of knowledge market by offering new and additional answers for demands in connection with training (Kovács, 2011). 
In Hungary neither the use of e-learning, nor building web 2.0 applications into classes have spread widely. Nowadays distance learning exists almost in all the developed countries. Distance learning has built Information and Communication Technology (ICT - tools, technologies, organizing acts, innovative processes that help and develop the making, spreading, storing and encoding of information and communication) (Magyar, 2012) into its methodology. With the spread of the Internet, e-learning can become popular as a new and effective educational form.

The results of this research help us to see the attitudes, habits and opinion of the actors in education. I think that the research about teachers is especially important. Within professional activity, competences of using digital tools and transmitting values have an important role. An important open question in higher education is how online educational environment will transform, if the use of e-learning materials will be popular, and if institutional ICT factors will be developed - including ICT competences of professors.

The paper attempts to give some answers to this research area. My main goal is to find out if there is a connection between age and the educational usage of online opportunities. The novelty of the paper is that the survey was made on a big sample. By examining the actual situation we will not only make a measurement, but also expand our knowledge about the opportunities and boundaries of using ICT in higher education. The study may help to map and understand the usage of digital tools and behavior in online environment of different generations in higher education. Therefore the research can be of help to higher education in finding its aims, regarding especially the development of curriculum supported by new technologies.

\section{Review of the Literature and Previous Researches}

Previous studies in this topic have shown us that education should open up towards IT improvements. In recent years the European Union has been emphasizing the improvement of digital competences and the modernization of education and it has been trying to create a national framework that may help people find the digital competences they need as European citizens (Ferrari 2013). There are many national and foreign studies dealing with higher education. These studies are trying to examine the situation of global and Hungarian online higher education and also trying to create some necessary changes. Among national studies I would like to highlight the works of Bessenyei (2007, 2011), Kulcsár (2008, 2009), Komenczi $(2006,2009,2013)$ and Ollé $(2010,2011)$. 
The present forms of formal education can not be maintained and they are not effective and flexible enough', therefore they are not eligible for the demands of knowledge based society (Duga, 2013). A new type of learning environment needs to be formed and it is necessary to use educational methods such as 'collaborative learning, problem based teaching, project works and cooperative learning'. In information society school is not the only place of learning and universities have to accept that the official curriculum is not the only source of information. In the new approach the role of teachers is changing, they are becoming mentors instead of mediators of information. The concept of connectivism - which is at the centre of the study - comes from Siemens and Downes. Following their works (Siemens, 2005, 2008; Downes, 2010), other learning theories connected to connectivism have been defined as well (the work of Bessenyei-Szirbik from 2011 gives us an extensive review of the topic).

Connectivism is building on the results of network research. In a review from Zsolt Kulcsár (2009): 'Connectivism means the application of network theories in pedagogy.'According to this method web 2.0 tools must be used in teaching to reach a successful education. With the help of these tools, effective online learning systems can be created. Due to new technological inventions, users of the Internet are becoming suppliers instead of consumers. Applications make it easier for users and participants to share contents and they change the ways of sharing, creating and using photos, texts, videos, events and connections. Web 2.0 applications build on communities, i.e. "users create contents together or share each other's information" (Szűts, 2014). Connectivist learning happens with the help of web 2.0 tools, i.e. every tool can be a specific inter-mediator of knowledge. They help to make information accessible and available to everyone. Some typical web 2.0 services are: "social sites, sound, photo and video sharing pages, blogs, micro-blogs, forums, social bookmarkings, editable cyclopedias, virtual words, podcasts, live casting services." New applications give a chance to students to cooperate and share information, and increase their motivation, commitment and self-expression (Siemens 2010). A new expectation for professors is to share their knowledge more efficiently by actively using IT. Professors think that certain applications can be valuable in education, while their opinions on using social media sites in learning are more problematic (Duga, 2013).

In a 2014 study by Zoltán Szűts, he examines the roles of contents created by users and social media sites in the interactive learning environment. "By applying digital tools and world wide web into everyday life", the way of getting information and the mechanism of learning have both transformed. It has become a daily routine for university students to visit social media sites, especially Facebook, which besides supplying information can also be an opportunity to create virtual learning groups. These groups usually deal with the implementation of courses 
and questions about bibliography, and sometimes professors can cooperate with them as well. Their main importance is in communication and cooperation between students. Due to technological development, the role of professors has changed, too. Instead of being the source of information, they rather function as moderators in the new environment (Szüts, 2014).

We can notice that in the process of getting information the role of the Internet is increasing, which is also a strong tendency in areas in connection with learning, as the importance of e-curriculum and e-sources is increasing. We can also state that a great number of users can not or can only use the opportunities of the Internet very poorly, regarding especially the reliability and validity of information, and there is some uncertainty around data protection, etiquette and digital competences as well (Sipos et al., 2015).

Bertalan Komenczi (2013) in his work, Electronic learning environments examined the opportunities of network learning and the Internet. During online learning, students connect to the curriculum interactively and individually, therefore teaching does not exist anymore. "Electronic info-communication technology is widening the possibilities of personal and sovereign learning", so contents can be reached in different modules, in database and according to personal demands. According to the author this way of learning "best integrates informal and spontaneous learning into the process of gaining knowledge" (Komenczi, 2013).

Courses building on network learning have a wide range of tools. For this I have used - among others - the works of Redecker, Ala-Mutka, Bacigalupo, Ferrari and Punie. Tom Franklin and Mark van Harmelen introduce how to apply web 2.0 tools into higher education with the examples of four universities.

A big difference in thinking can be seen between students and professors, which creates a barrier to successful teaching (Ollé, 2012). The learning habits of Internet generation are affected by the fact that they spend more and more time using web 2.0 applications therefore creating a unique - and still unutilized opportunity for higher education. Nowadays existing educational systems work less efficiently with the new generation; in higher education "students mostly from generations $Y$ and $Z$ have different characteristics, therefore they need a different kind of education as well" (Pais, 2013). Those youngsters who were born into digital technology are now participants in higher education; for them online world belongs to everyday life. Applying web 2.0 applications into education could increase their motivation, commitment, and expression of opinions and could encourage dialogue.

Generation research uses grouping by year of birth. International studies use the term digital natives for the generation who grew up with the Internet based on Digital natives, digital immigrants (2001) by Mark Prensky. But what 
do we mean by the term generation? Those belong to the same generation (Mccrindle \& Wolfinger, 2010, quoted by Pál, 2013) who were born in the same period of time, they are the same age and in the same period of life and therefore they have been affected by the same technology and experiences (Pál, 2013, p. 5). Certain generations have different life orientation, they have similar beliefs and behaviors regarding family, career, religion or politics (Howe and Strauss 2000, quoted by Pál, 2013). Generational approach is often accused of not consisting of unified and homogenous groups but of pseudo-communities. It is important to note that there are overlaps between generations and the borderlines are not clear, so grouping can be problematic. There are different theories and ideas around whether it is possible to call a group of people born in the same time a generation, and if it is, around how they can be put into groups (Karvalics, 2001). The generation picture introduced (or rather created) by Prensky is often criticized, because it is not technology that determines the usage of media and habits of communication among youngsters, but the socio-cultural factors which have been forming the usage of digital technologies ever since (Szijártó, 2013).

\section{Methodology}

\section{Structure of the research hypothesis}

I prefer the questionnaire survey, as the essence of quantitative research is oriented to systematically collect data, and critical processing. The basic research question is how the age factor (and the resulting generational differences) affect Internet use, and attitudes to ICT factors for educators. On the basis of the theoretical literature, numerous differences are assumed in several important areas.

The paper presents the results of an online survey in detail. In addition to the online survey methodology, there are many arguments presented as well. The questionnaire advantage of pre-recorded questions is that we ask everyone to author reliable and fast data process. The online query is practical, since the data capture, processing, and the analysis of information becomes easier. The online questionnaire's big advantage is that there is no interviewer bias, and any sensitive questions can be addressed honestly by the respondents.

The answers can be easily quantifiable and can be processed, and due to standardization, the results are comparable, and sophisticated statistical methods may be used in the data analysis. 148 people responded to the survey. I think that on the basis of the number and composition of the sample - if not completely representative $-\mathrm{I}$ got a realistic picture of the current issues. Considering the 
nature of my research it is both general and specific. It gives a clear picture of the nature of higher education and ICT factors in the current situation, and more specifically - it is looking for answers to defined questions, particularly with respect to a particular institution (University of Pécs).

Processing of the coded data was done using the SPSS statistical data processing software. The statistical data charts were subjected to tested methods ( $t$ -test, Chi-square test, Fisher test), indicating the values and significance in the Appendix. In this paper, I examine questionnaires comprehensively, address my research questions and make conclusions on the basis of the data. Some of my conclusions are directed at age, rather than offering a comprehensive analysis of data from the teaching pattern. I also looked for answers to the kind of detectable differences between the students and teachers in regarding the comparison of attitudes on ICT factors. Before starting the research I made made my hypothesis based on the specific literature review and on lessons learned from previous studies with similar demographics. The research is deductive: the assumptions are made on the basis of theory and empirical testing of hypotheses to decide whether it will be justified, convertible or rejected.

H1 hypothesis: teachers working in higher education, prefer education-related ICT tools with traditional teaching methodology, the web 2.0 is relegated to the background.

$\mathrm{H} 2$ hypothesis: the usefulness of different ICT tools is perceived as different from the student and teacher evaluations.

H3 hypothesis: the reason for the low number of higher education courses online is that there is no objective, institutional, personal and educational criteria.

I will present the data that were obtained by questionnaires in the second half of the thesis - for the ease of understanding- sistematically with the help of diagrams. Examination of hypotheses has been the part of the research paper.

\section{Instructor questionary survey and The technical implementation and query process of data collecting}

The questionnaire was completed in 2016 as a Google document and could only be completed online. The persons who filled the forms were the teachers at the University of Pécs. They were invited via e-mail to participate in the survey and got the link of the questionnaire. The emphasis was placed on ICT (information and communication technology) device use, and most of the issues were related 
to this. In addition, I asked about the ICT supported education and pedagogical methods and I also asked questions about institutional factors, but the students have been examined according to their attitudes towards it (competencies for future generations). I finalized the questionnaire on the basis of the results of the test interviews. The final version of the questionnaire contained 27 questions.

The questions can be divided into three parts based on their types. For the first type only one answer could be selected, with the second type there were more possible answers, at the third type of questions (or statements) was evaluated using a multi -point scale. The survey was administered in February 2016, and a total of 148 evaluable responses were received. The data analysis was done using SPSS statistical evaluation system that has been presented in the Introduction.

In this sample I also analyzed the response patterns according to the age division. Based on age, I created three groups (Generation Y, Generation X, Baby Boomers generation), and the three groups have been formed as follows:

1. groups: up to age of 35 ; this group contained 32 people;

2. group: ages $35-55$; this group contained 84 persons;

3 . group: ages over 55 ; this group contained 32 people.

This offered a possibility of a statistical analysis of the three age groups involved, devided by age group based on crosstabs. Where this was not possible, I could rely on statistical methods. In drawing conclusions and presenting the results I try to look out of the concept system of generation categorization and its interpretation frame.

\section{Results}

( $1^{\text {st }}$ Question: What is your gender?)

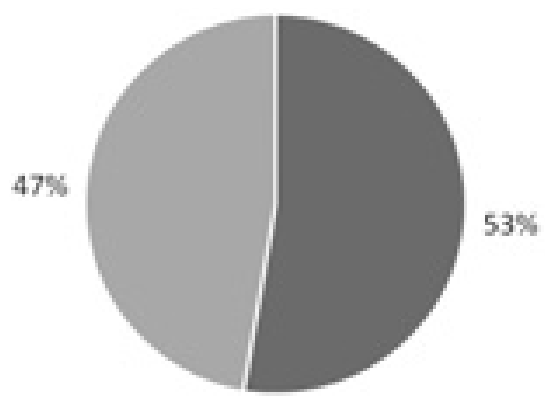

148 people gave evaluable response in the examination sample. The gender distribu-

- Female tion of the sample is shown in the following diagram. The questionnaire was filled by 78 women $(53 \%)$ and 70 men (47\%) (Figure 1).

Figure 1: Gender rates of the examined model. Own design. 
(2nd Question: What is your age?)

32 people younger than 35 (21.6\%), 84 people aged 35-55 (56.8\%) and 32 people over 55 years of age $(21.6 \%)$ were involved. As the diagram shows, the 35-55 year olds had the largest proportion among the people who participated in the filling of the questionnaire (Figure 2).

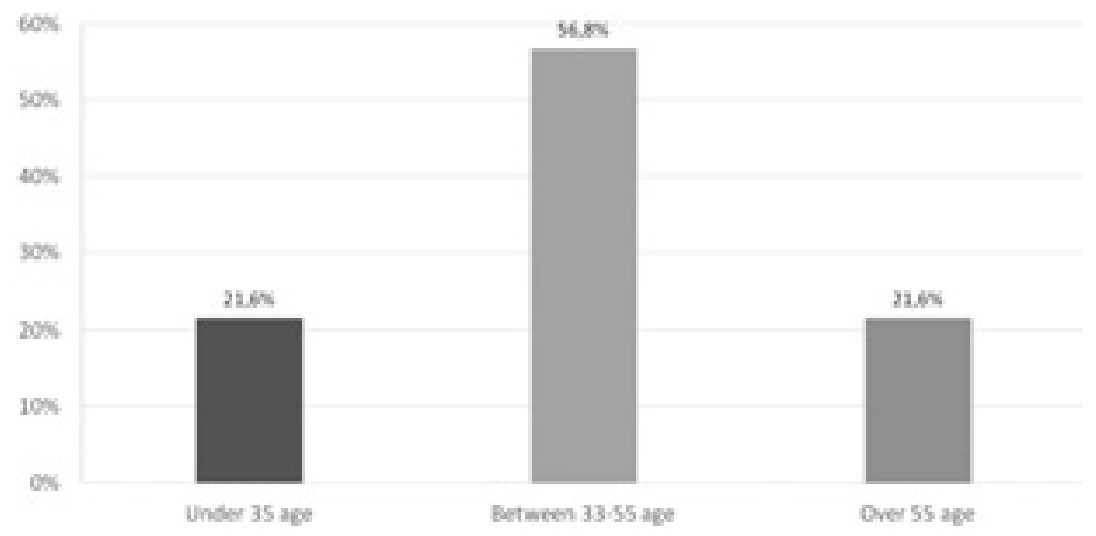

Figure 2: The examined model division per ages. Own design

(3 ${ }^{\text {rd }}$ Question: How long have you been teaching at the university?)

Out of all of the survey respondents, $45.3 \%$ (67 persons) have been teaching for maximum 10 years, $31.1 \%$ (46 people) for $11-20$ years, $10.8 \%$ (16 people) for 21-30 years, $2 \%$ (3 people) for $41-50$ years, (Figure 2 )

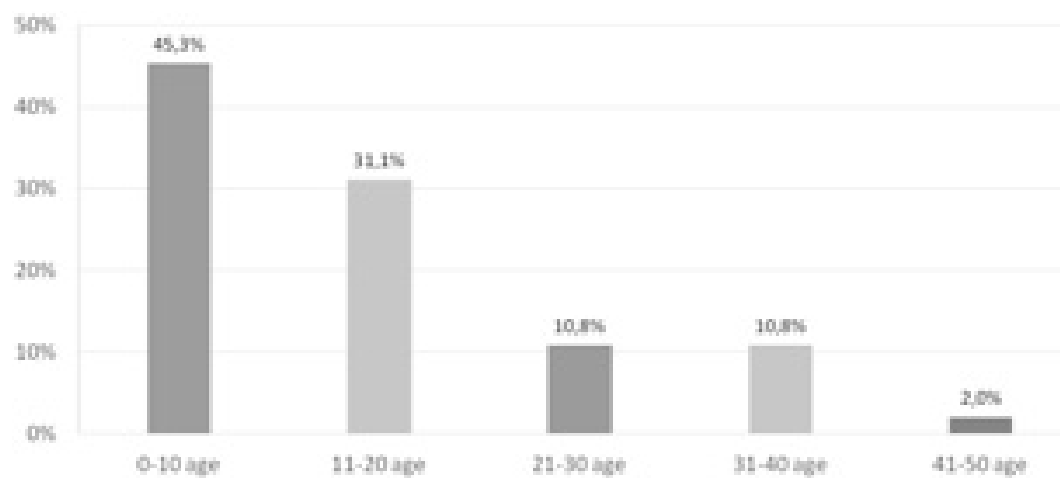

Figure 3: School-time spent at university. Own design. 
(4 ${ }^{\text {th }}$ Question: Which discipline do you teach?)

The majority of respondents, $33 \%$ (48 people) are educators in the field of medicine and health sciences. 19\% (28 people) work in social sciences, 16\% (24 people) in liberal arts, 7\% (11 people) in the natural sciences. $8 \%$ (11 people) in economics, 6\% (nine persons) Representatives of State and Law, 5\% (eight persons) in technical sciences, $4 \%$ (six persons) in IT, two in pedagogy, and one person working in the field of linguistics (Figure 4).
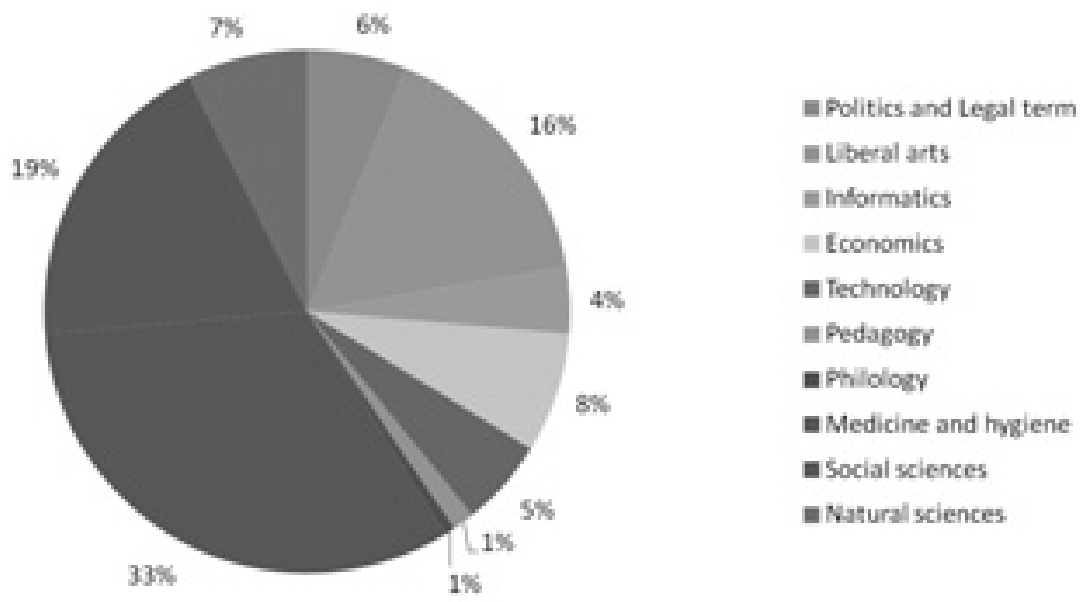

Figure 4: Respondents' division as discipline. Own desgin.

(5 ${ }^{\text {th }}$ Question: Which faculty do you teach at?)

$31.1 \%$ (46 people) of the respondents teach at the Faculty of Medicine, 19. 6\% (29 people), at the Faculty of Arts, 16. 9\% (25 people) in Cultural Studies and Faculty of Pedagogy and Rural Development, 7. 4\% of the Faculty of Law, Faculty of Engineering and Information Technology Faculty and the Faculty of Science faculty, teacher's ratio is $6.8 \%$ (10-10 people). $4.1 \%$ (6 people) in the Faculty of Health Sciences, $0.7 \%\left(1\right.$ person) teaches at Arts Faculty $\left(5^{\text {th }}\right.$ diagram). The sample is not fully representative, but represents PTE's diversity (Figure 5). 


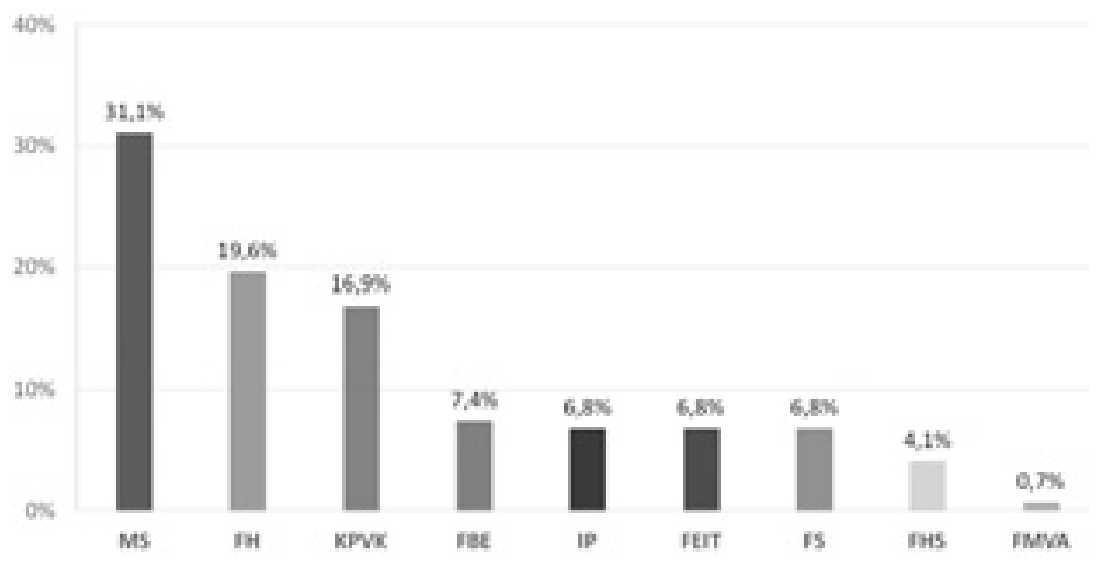

Figure 5: Respondents' division as faculties. Own desgin.

( $\sigma^{\text {th }}$ Question: Do you use the following ICT tools in your own lessons?)

The summary shows clearly that the teachers use the computer, the projector and the slide show (ppt) most often during teaching. This is followed by the e-learning materials and online Learning Management Interface (Neptun). Less frequently used tools are Wikipedia, the camera and the smart phone. The least used tool among the respondents is the interactive whiteboard (Figure 6).

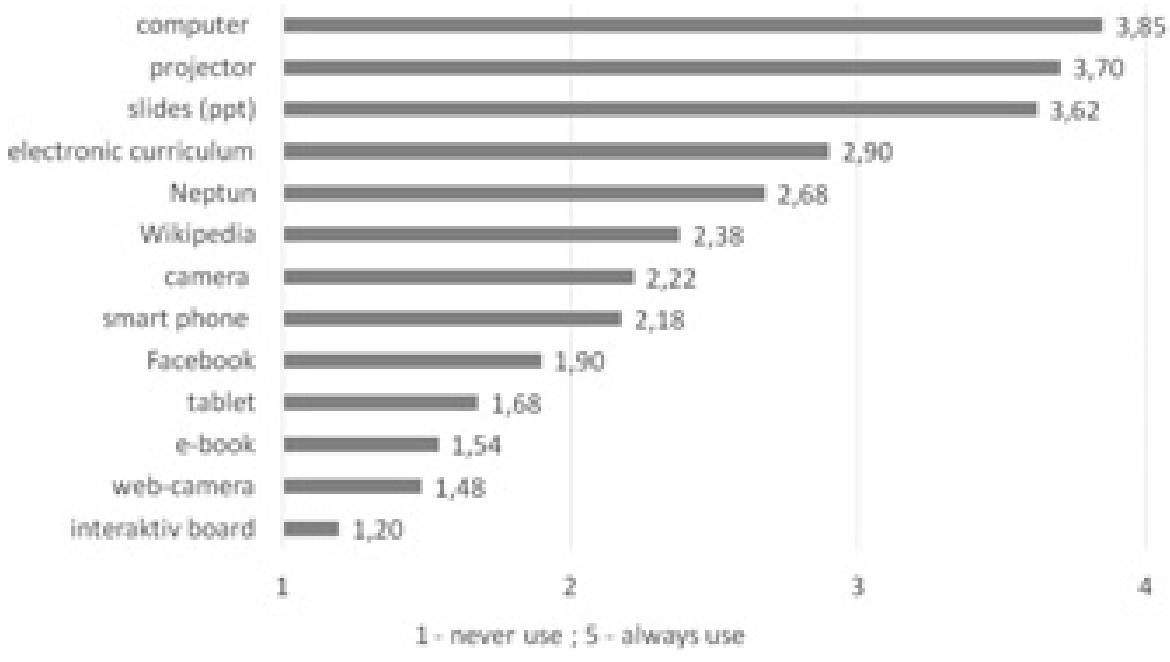

Figure 6: Respondents' division as using ICT equipments. Own desgin. 
There is a significant difference in the frequency of the use of the smartphone in the age groups. Among respondents who stated that they their smartphone for educational work were $31.3 \%$ of those younger than 35 , and less than $20 \%$ of $35-55$ year olds and those over 55 .

\section{(7th Question: Do you feel prepared for the usage of the following IT tools?)}

This diagram shows how the teachers consider themselves being prepared for the usage of ICT tools. The previous question has shown that the teachers use computer, projector and slide show (ppt) most commonly in their teaching activities. The highest rate was in slide show, projector and in computer usage. Teachers were relatively confident in terms of e- learning materials, and usage of the cameras as well. This was followed by the reduced usage of the Wikipedia, Web camera, smartphone, tablet devices. As for the usage of Facebook and Neptun, the picture is quite similar to the previous ones. The tool that they were most uncertain about is the use of the interactive whiteboard (Figure 7).

Independently of age of the respondents, they feel prepared for the usage of other information technology devices we have listed to the same extent.

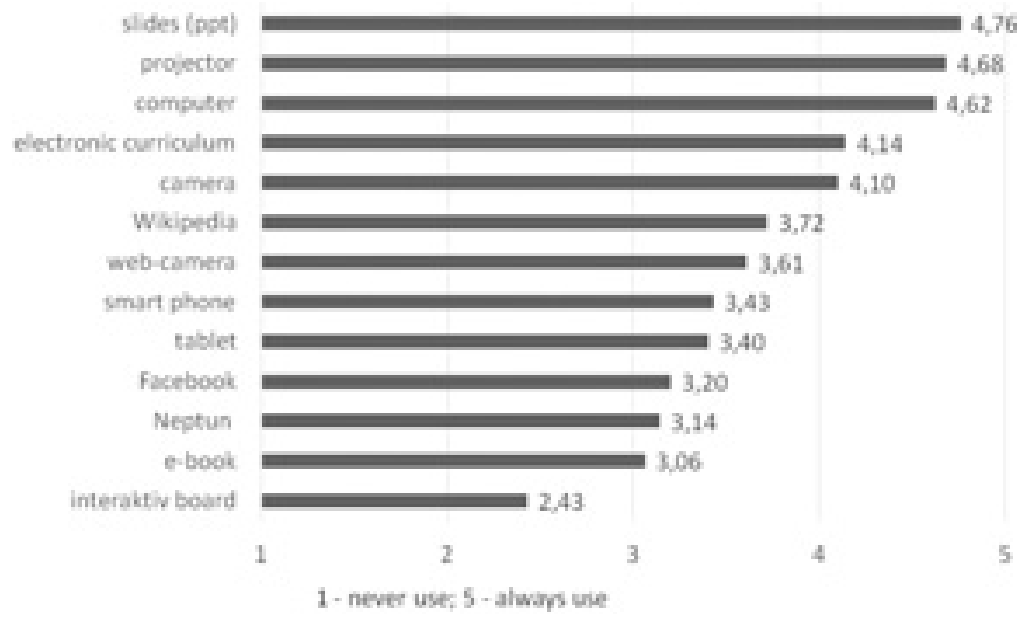

Figure 7: Respondents' division as their preparadnes using ICT equipments. Own desgin.

(8 $8^{\text {th }}$ Question: How is the institution's facilities in the field of ICT?)

According to almost half of the respondents (48\%, 71 persons) the institutions lack the equipment needed for the ICT tools. According to $45 \%$ (67 people) it 
is adequate, and only $7 \%$ (10 people) believe that they have everything they need (Figure 8).

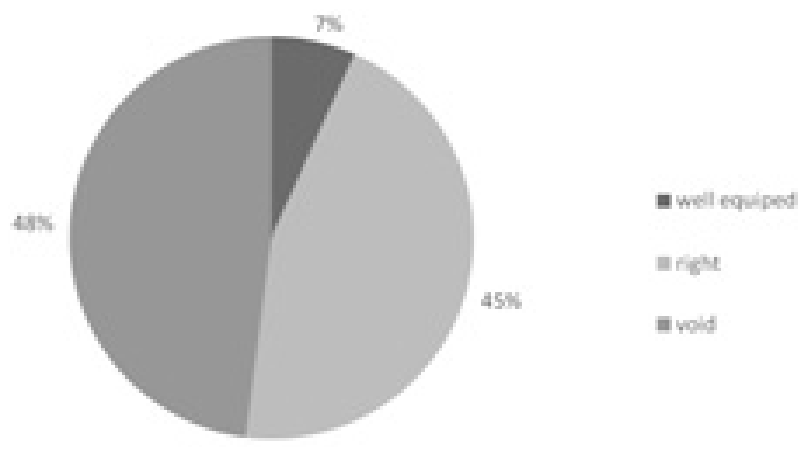

Figure 8: Respondents' division as ICT facilities of institutions. Own desgin.

(9th Question: Are you supported by the institution in the use of ICT tools and training opportunities?)

$29.7 \%$ (44 people) of the respondents are not supported by the institution in the use of ICT tools and training opportunities. $16.2 \%$ of (24 persons) are not supported with any ICT equipment, but they are given the opportunity to train themselves. $20.9 \%$ ( 31 people) are supported by ICT tools, but with no training opportunities. One third of the teachers, $33.1 \%$ ( 35 persons), is provided the tools and further training opportunities by their institutions (Figure 9).

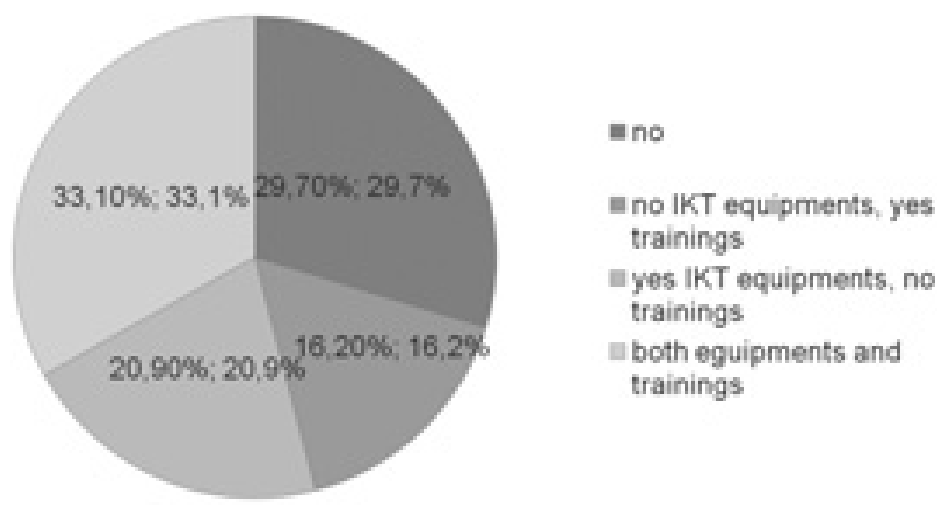

Figure 9: Respondents' division as institutional support. Own design. 
(10 Question: Are there any opportunities to attend lectures given by others, where the ICT tools are used frequently?)

$56.8 \%$ of the lecturers (84 people) have the opportunity, $43.2 \%$ (64 people) do not. Such demonstrations can be an important advantage where educators learn about the usage of different tools and it can help them in applying these tools in their lessons more often. However, almost half of the respondents do not have this possibility (Figure 10).

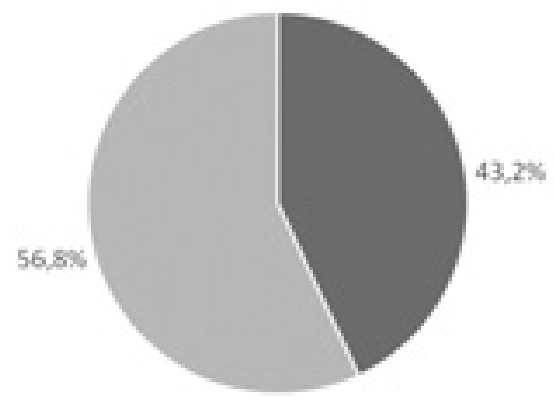

- not organised $=$ yes, there is

Figure 10: Respondents' division according to participation in other teacher lectures. Own design.

(1 $1^{\text {th }}$ Question: Do you take part in such forums (including online ones) where you have the possibility to get information about the tools that you have not used yet?)

$35.8 \%$ of the respondents (53 people) participate in forums where they are informed about new methods or technical information. $64.2 \%$ (95 people) have not participated in such programs (Figure 11.1).
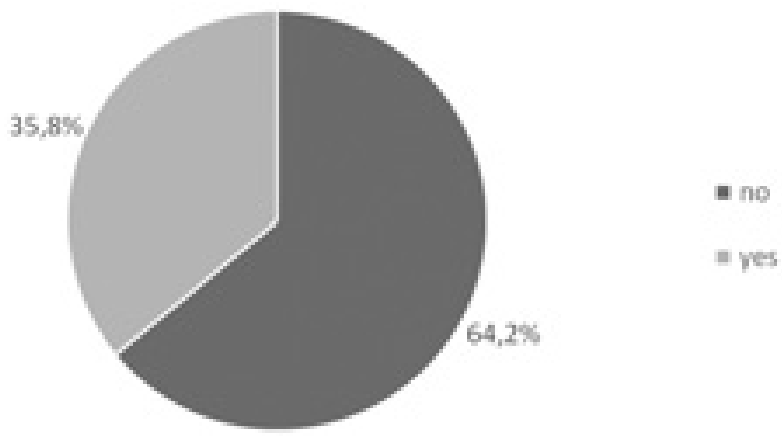

Figure 11.1: Respondents' division as participation on forums. Own design. 
These four issues concerning institutional ICT factors were taken under consideration. The results of the research seem to support my hypothesis that the institutional provision of ICT tools and the institutional support is inadequate. $48 \%$ of the survey respondednts ( $8^{\text {th }}$ diagram) believe that there are institutional deficiencies in ICT facilities. If we examine the results on the basis of age groups, it will be clear that regardless of age, the teachers think the same way about the equipment in their institutions.

However, there is a significant correlation between how the institution's equipment is viewed from the aspect of ICT and whether there is a possibility of attending lectures where ICT facilities are used. $(P=0.015)$. Those who believe that the institution lacks of ICT facilities, admit in larger proportion that there is no opportunity to participate in such lectures than those who are least satisfied with the institutional supply in this area (Figure 11.2), (Appendix, $3^{\text {rd }}$ table $8^{\text {th }}$ question;).

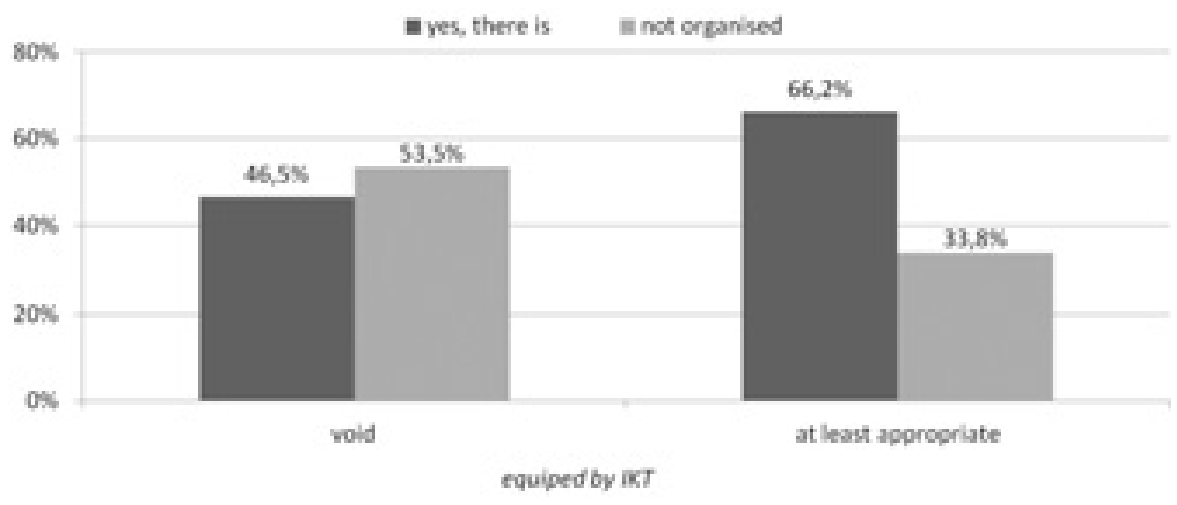

Figure 11.2: Satisfaction with facilities and opportunities to take part in lectures held by others who use ICT equipments regularly. Own design.

\section{(12 $2^{\text {th }}$ Question: What is your opinion of the usefulness of ICT tools}

in the classroom environment?)

The tool deemed the most useful is the projector, the slide show and the computer. most of which are used on a daily basis by the lecturers. E-learning is in the fourth place, followed by the interactive whiteboard. This is also interesting because in earlier questions, this device was reported to be used rarely and its usage uncertain. There could also be a question for further research of why the e- book reader is classified educationally backward. Facebook received the lowest 
evaluation of ICT devices. According to this, most of the teachers do not support this tool in classroom environment (Figure 12)

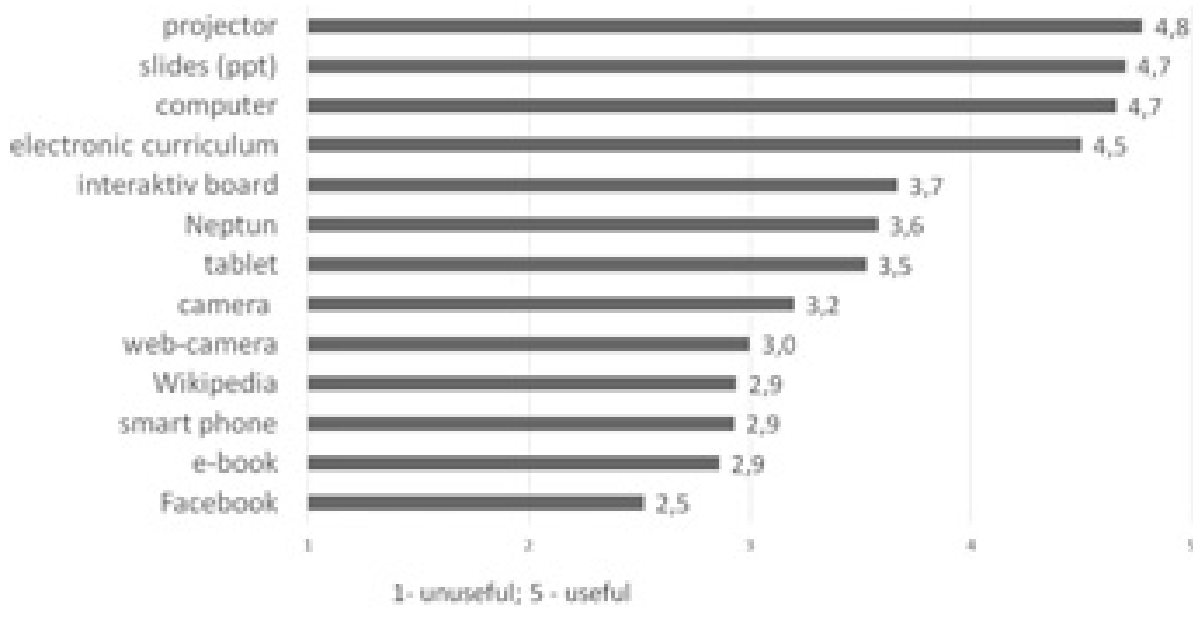

Figure 12: Respondents' opinion on the usefulness of ICT equipments used on lessons. Own design.

In the instructors' work, the use of Wikipedia, webcam and e-learning showed generational differences. People over 55 prefer to use Wikipedia and Webcam. The fact that the instructors consider Wikipedia as an ICT tool more useful, is significantly associated with age $(\mathrm{p}=0.033)$.

People over 55 considered Wikipedia useful (31.2\%), while 12.5\% of those younger than 35 and $11.9 \%$ of $35-55$ year olds share the same opinion (Appendix, $1^{\text {st }}$ chart, $12^{\text {th }}$ question).

There is a substantial difference in the proportion of the age-based questionnaires who consider webcam useful. $(p=0,049)$. Using webcam in the school environment is considered the most useful in the group of $55+(25 \%)$, while $35-55$ year olds $(17,9 \%)$ and $3,1 \%$ of people younger than 37 have the opinion that the usage of webcam is useful (Appendix, $1^{\text {st }}$ chart, $12^{\text {th }}$ question).

(13 $3^{\text {th }}$ Question: What are the ICT devices that are most commonly used in the field of your educational work?)

More devices could be mentioned in the answers. The order is stable. $88.5 \%$ of the respondents (131 people) gave computers as an answer, $9.5 \%$ (14 people) said they used laptops, and $57.4 \%$ ( 85 people) consider projector as the most useful device. In the opinion of $45.3 \%$ (67 people) of the instructors slide show / ppt should be listed here too. Only $17.6 \%$ (26 people) gave e- learning materials 
as their answer, $10.8 \%$ (16 people) gave tablet and $9.5 \%$ (14 people) said they used the interactive whiteboard (Figure 13).

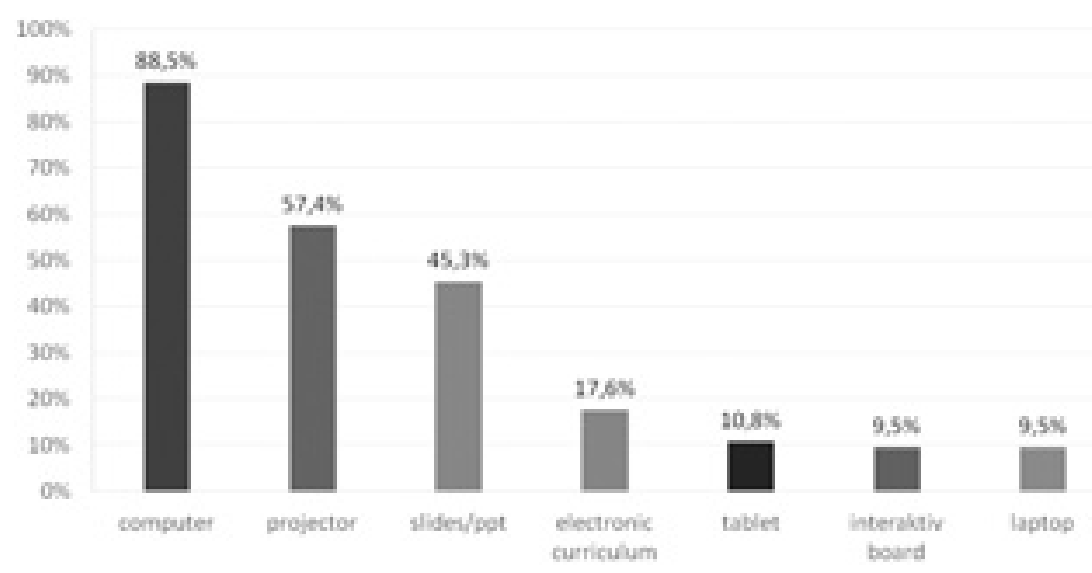

Figure 13: Most used ICT equipment in respondents' special fields. Own design.

(14th Question: If you use ICT tools in the classroom, how often do you do this?) $69.6 \%$ (103 people) of the lecturers who took part in filling out the questionnaire use ICT tools in all of their lessons. 16.2\% (24 persons), use ICT tools only if necessary, $8.1 \%$ (12 people) on a weekly basis, $3.4 \%$ (five people) rarely, $2.0 \%$ (three persons) monthly, and $0.7 \%$ (one person) never uses ICT tools (Figure 14).

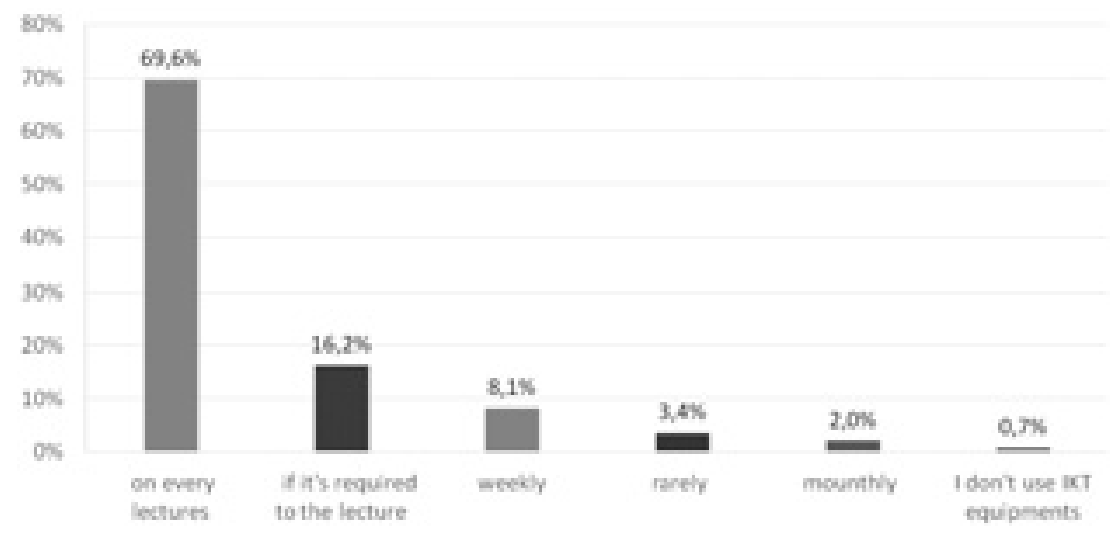

Figure 14: Respondents' division regarding the frequency of ICT equipment use in lessons. Own design. 
$15^{\text {th }}$ Question: Which of the following sources do you use in your digital lessons, or when preparing?)

Almost everyone who filled the questionnaire, $97.0 \%$ (144 people) use images, or diagrams. The use of digital text elements is less pronounced, with about 77.0 $\%$ (114 people). Surprisingly, many people, more than half of the respondents (65.0 \%, 97 persons) use videos during their lessons. Simulation is used by 25.0 $\%$ of the respondents (37 people), music 12.2\% (18 persons), $6.1 \%$ use games (nine people) and 5.8\% (eight people) use other sources (such as 3D text databases, websites, images). (Figure 15)

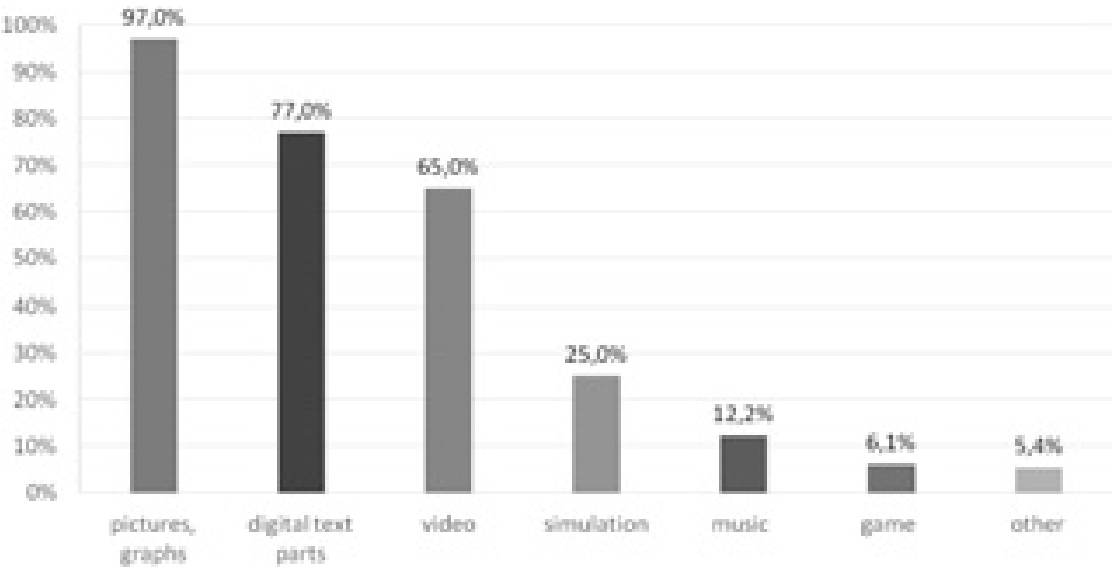

Figure 15: Respondents' division regarding use of digital sources for preparation. Own design.

\section{(16 $6^{\text {th }}$ Question: Which of the following pedagogical methods do you apply?)}

The most common method of teaching was to lecture-style instruction, as $91 \%$ of respondents ( 135 people) think that the most common method of teaching is delivering content through lecturing. This is followed by explanation $86 \%$ (127 people); the discussion is used by $81 \%$ (121 people), the teamwork by $65 \%$ (96 people), project work by $44 \%$ (65 people), the argument method by $36 \%$ (57 people), computer methods by $35 \%$ (51 people) and finally the other' category was chosen by $5 \%$ (seven people). (Figure 16.1)

It is interesting to note that using the Fisher exact test, the results show that there is a significant difference between the teachers over 55, and the 55 years old or younger in how they use the front-of-classroom lecture style or the explanation. These methods are used by 55 year-olds and younger, more so than 
by those who are older than 55: lecture-style $(\mathrm{p}=0.035)$, explanation $(\mathrm{p}=0.035)$ (Appendix, second chart, $16^{\text {th }}$ question) (Figure 16.2).

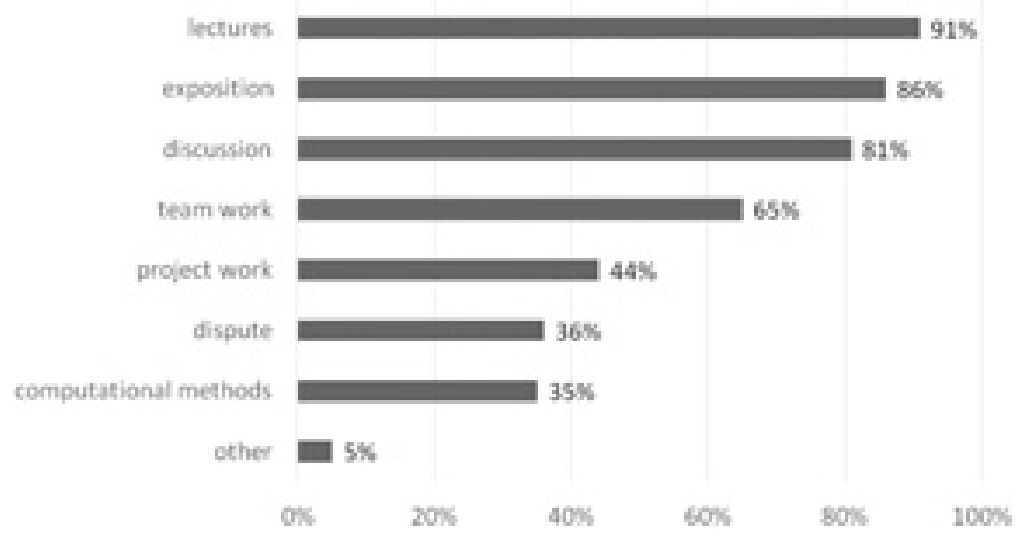

Figure 16.1: Respondents' division regarding the use of pedagogical methods. Own design.

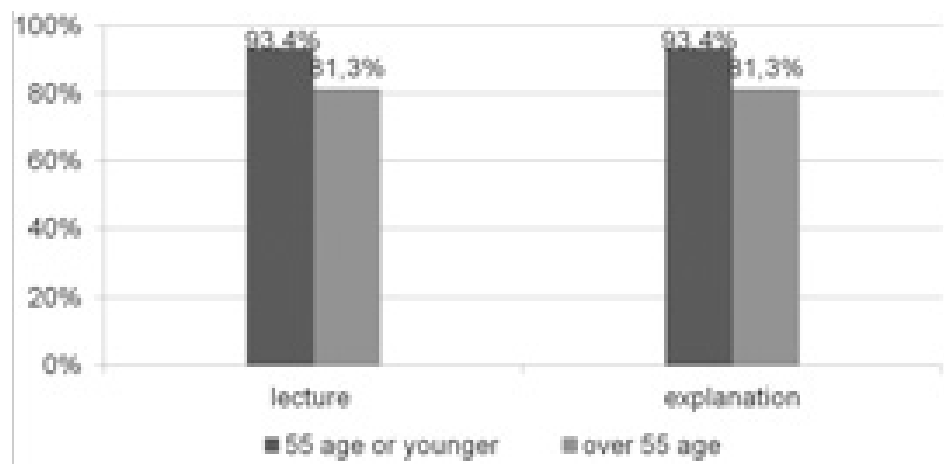

Figure 16.2: Distribution of pedagogical methods. Own design.

(17 Question: What new teaching methods do you consider to be important and useful?)

$76.2 \%$ of the respondents (112 people) consider the co-operative techniques as the most important new pedagogical methods. $68 \%$ of them (100 people) consider the project work also good to use. In the third place is the multimedia $50.3 \%$ (74 people). $25.9 \%$ (38 people) responded with 'other', while $12.2 \%$ (18 people) think the usage of web 2.0 asset is important (Figure 17). 


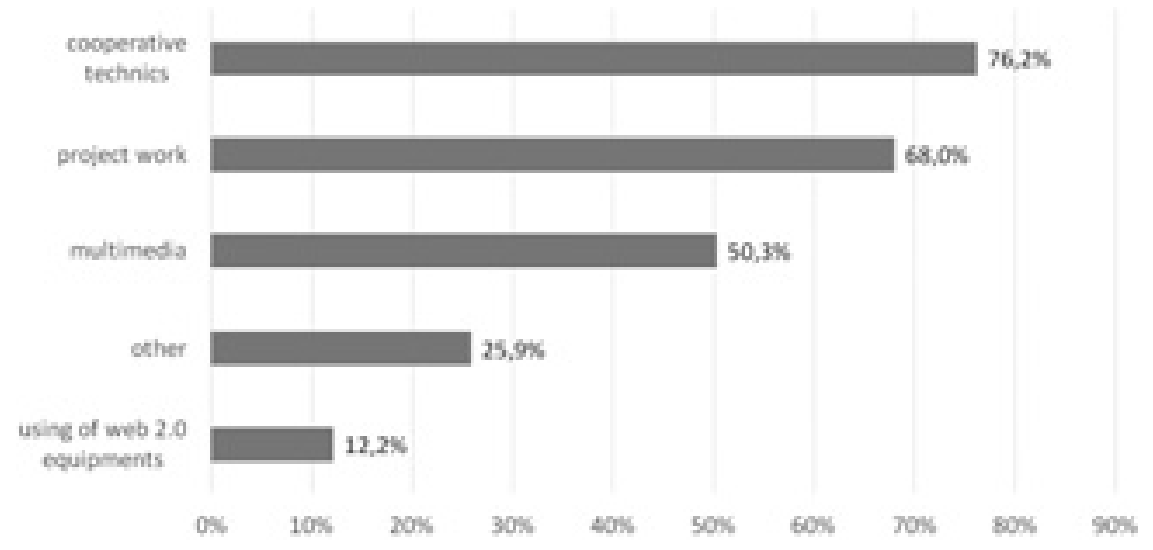

Figure 17: Respondents' opinion of the new pedagogy methods. Own design.

(18 $8^{\text {th }}$ Question: Do you think the use of advanced tools is associated with the use of new teaching methods?)

For $83.8 \%$ of the respondents (124 people), the use of advanced tools is associated with the use of new teaching methods, while $16.2 \%$ (24 people) do not think in this way (Figure 18).

Figure 18: Respondents' opinion of using the modern equipments means using them in pedagogy as well. Own design.

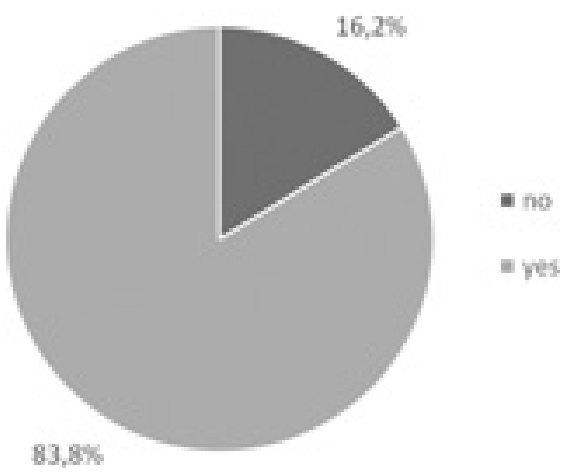

(19th Question: Do you think that there is an interaction between the use of new teaching methods and IT competencies?)

$95.9 \%$ of the teachers (142 people) say that there is interaction between new teaching methods and IT competencies, while only $4.1 \%$ (6 people) claims that there is no interaction (Figure 19). 
Figure 19: Respondents' opinion about effects of pedagogical methods and informatic competency on each other. Own design.

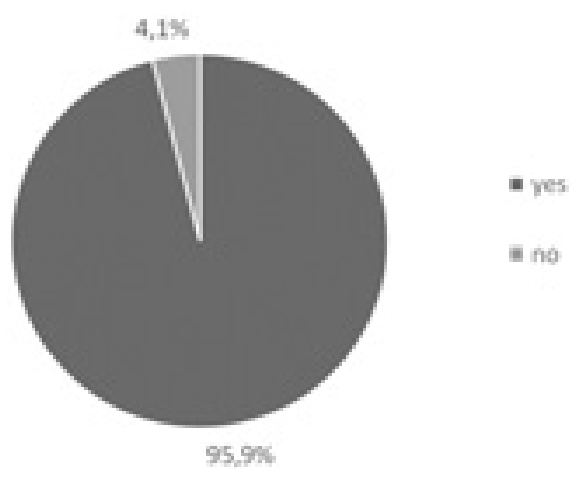

(20 th Question: What kind of students' competencies do you consider important in relation to the subjects you teach?)

Among the instructors, 97\% (143 people) think the most important skills for students are for them to understand the correlations. This is followed by the reading comprehension, held as important by $85 \%$ (125 people), the systematic capacity stated by $76 \%$ (113 people), inductive reasoning by $72 \%$ (107 people), the ability of abstraction by $60 \%$ (88 people), and finally $7 \%$ (11 people) chose 'other' (Figure 20).

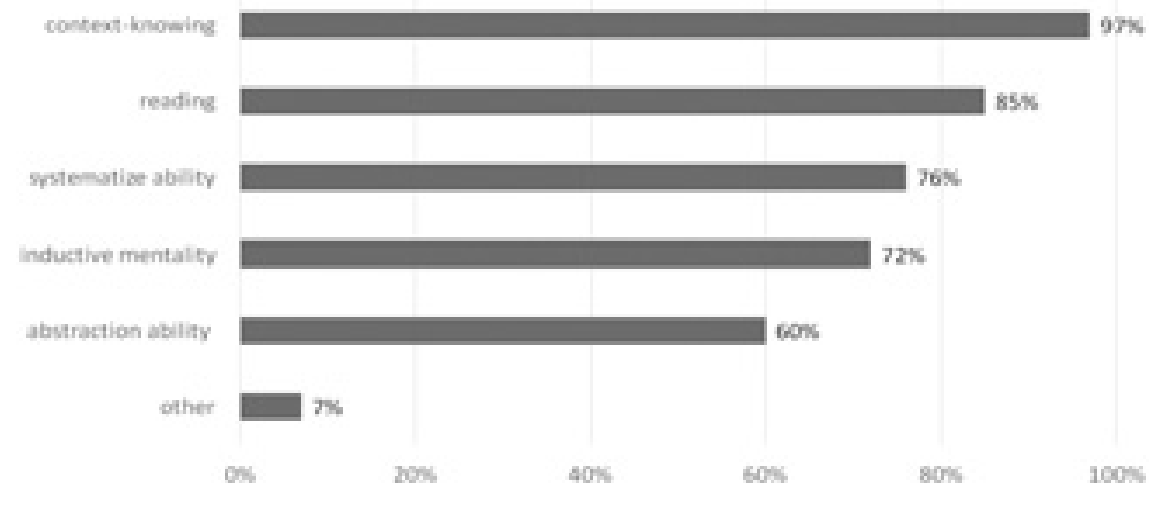

Figure 20: Respondents' division as regqading important students' competencies. Own design.

(21 $1^{\text {th }}$ Question: Does the use of ICT tools help the development of these competencies?)

According to $86.6 \%$ of the teachers (129 people), the development of the aforementioned competences is promoted by the use of ICT tools. $13.4 \%$ (19 
people) believe that there is no help afforded to the development by ICT tools (Figure 21).

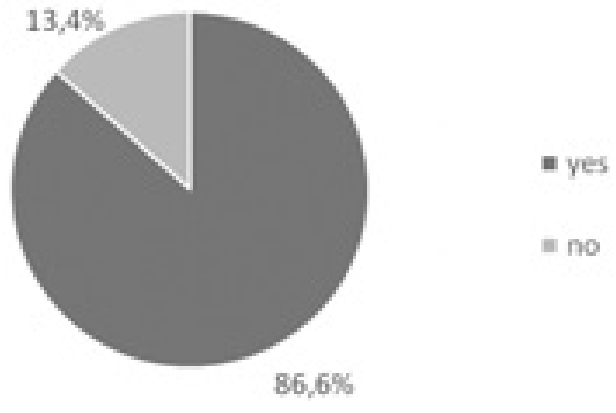

Figure 21: Respondents' opinion on whether using ICT equipment helps with development of students' competencies. Own design.

(22 th Question: Which teaching activities among the following are the most typical?)

It can be said that among the respondents the most popular is the slide show presentation of the curriculum. Two-thirds of the sample give interactive and cooperative lessons. The above mentioned - frontal teaching techniques used by teachers got first place earlier but in this question it was pushed into third place.

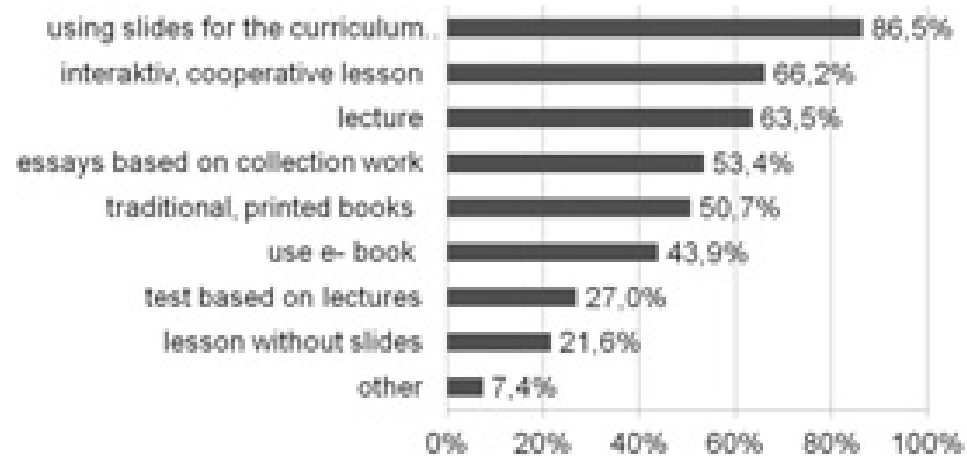

Figure 22.1: Respondents' division regarding most-significant opportunities in tutorial activity. Own design.

$86.5 \%$ of the respondents (128 people) marked slide show as typical teaching activities, $66.2 \%$ (98 people) think interactive and cooperative classes characteristic of their teaching, $63.5 \%$ (94 people) think this of the frontal education, $53.4 \%$ (79 people) of hand in home paper that is prepared on their 
own investigation. $50.7 \%$ (75 people) of the use of usual, printed version of workbooks, 43.9\% (65 people) of the use of electronic workbooks, 27\% (40 people) of the test papaer of the previously frontally taught curriculum, 21.6\% (32 people) of the lesson without slide show, $7.4 \%$ (11 people) chose other possibilities (Figure 22.1).

There is a significant connection between the three age groups we studied, and whether the respondent considers typical of his/her own educational activities the use of the traditional printed textbook or not. $(p=0.046) .56 .3 \%$ of those younger than $35,56 \%$ of $35-55$ year olds, and $31.3 \%$ of 55 yrs or older admitted that this is one of the most characteristic features in his or her teaching (Appendix, first chart, 22 $2^{\text {nd }}$ question), (Figure 22.2).

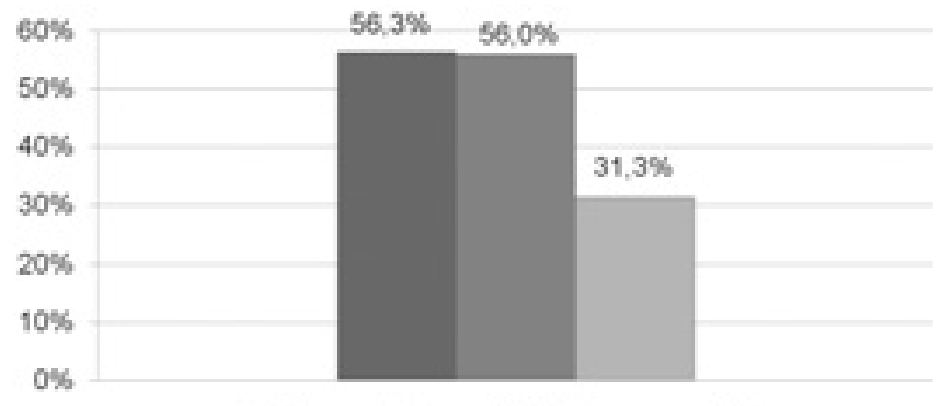

= under 35 age $=$ between $35-55$ age $=$ over 55 age

Figure 22.2: Division regarding the evaluation of using traditional, printed books. Own design.

(23 ${ }^{\text {rd }}$ Question: Do the students have the possibility of realizing the two-way communication in your class?)

91.9\% of the instructors (136 people) give the opportunity for the students to implement a two-way communication, $2.7 \%$ (fourpeople) do not, and $5.4 \%$ (eight people) marked other possible answers (Figure 23).
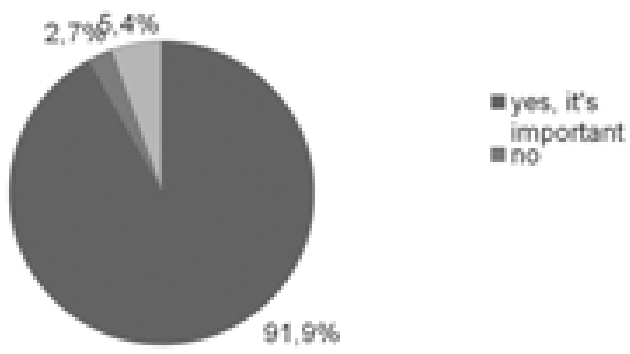

Figure 23: Respondents' division regarding the possibility for interactive communication in lessons. Own design. 
(24th Question: What is the attitude of the management towards the institution's ICT devices?)

$45.3 \%$ of the respondents (67 people) have poor possibility to use ICT tools in their workplace. $41.2 \%$ (61 people) stated that the management encourages their use, $4.7 \%$ (7 people) feel that the institution is completely uninterested in it, and $8.8 \%$ (13 persons) marked other categories (Figure 24).

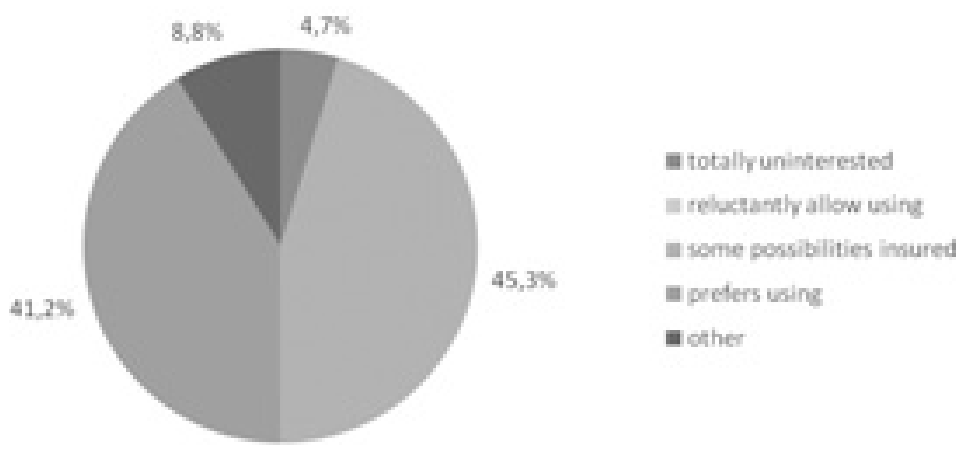

Figure 24: Respondents' division on attitudes of the institutions' leaders to tICT equipment. Own design.

(25 ${ }^{\text {th }}$ Question: Evaluate the following methods, depending on how often you use them in university education!)

The teachers who filled the questionnaire apply the group problem solving method as the most common one of the university education methods listed. This is followed by discussion and student presentations. The diagram shows that the valuation is not too high, so that every lesson is not likely to be built for these procedures (Figure 25).

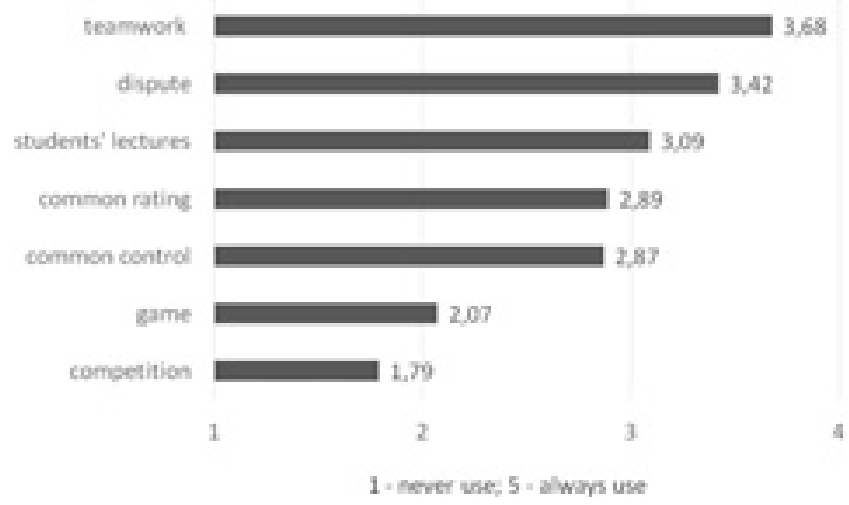

Figure 25: Respondents' opinion about pedagogical methods in education. Own design. 


\section{(26 $6^{\text {th }}$ Question: Do you agree with the following statements?)}

The different age groups in similar proportions agree or disagree with the statements below. There is no significant relationship between age and whether they agree or not with these statements. Many people chose do not know / no answer options (Figure 26).

Almost all the people who filled the questionnaire (over 90\%) agreed with the usage of computers and digital textbooks in education and their justifiability Many people believe that the projection of additional content (slides, photos) does not distract students, attention from the teacher. As was seen, with previous items projectors and slide shows are intensively used in higher education.

More than two thirds of the sample believes that mobile phones / tablets / e - readers, the interactive whiteboard and the introduction of similar tools for public education put pressure on teachers unnecessarily. The results are detailed in Conclusions section .

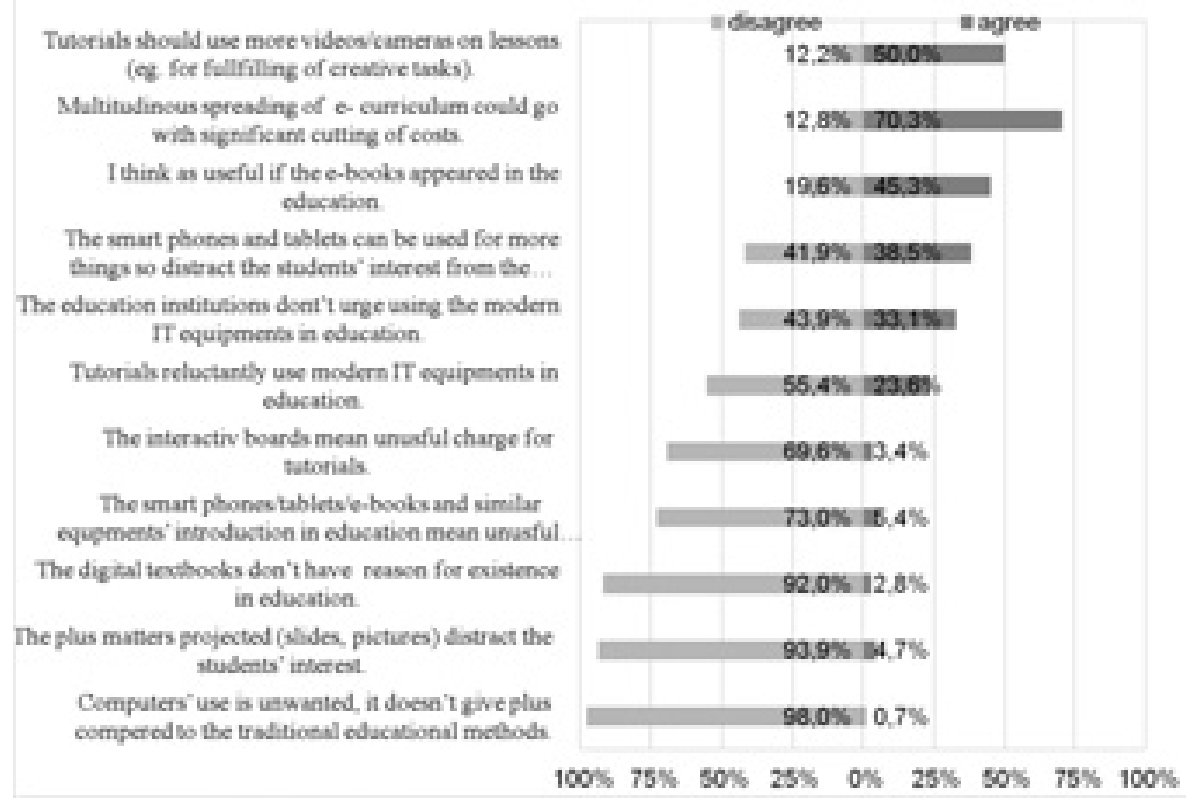

Figure 26: Evaluation of the following statements. Own design. 
(27 Question: Do you agree with the following statements concerning the $Z$ generation (aged under 20) of students ?)

Again, there is no significant relationship found on the basis of age groups. In connection with the statements referring to generation $\mathrm{Z}$, there was high agreement (over $80 \%$ ) on three observations::

The visual stimuli are important for today's students, and also have a huge impact on them. Today's students need enrichment. Today's students are not smarter, they just think in a different way than their predecessors (Figure 27).

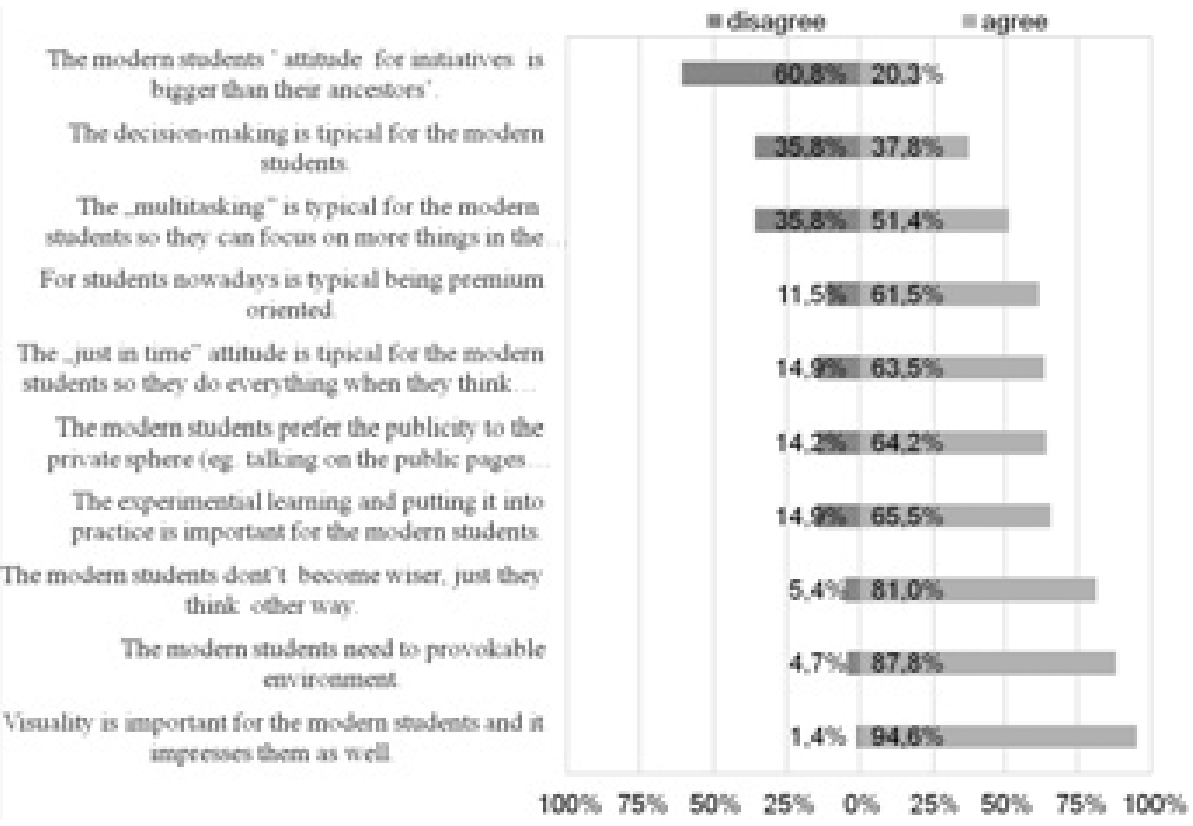

Figure 27: Evaluation of the following statements. Own design.

I studied the ICT educational tools ranked on usefulness, comparing the student and teacher evaluations. Here, respondents scored the ICT devices on a five- point scale, and both of the questionnaires included the following questions: What is your opinion about the usefulness of the following ICT tools in educational environment?

There were significant diversities found in responses: the students significantly appreciated the following ICT devices: smartphones $(\mathrm{p}=0.000)$, tablet $(\mathrm{p}=$ $0.007)$, Wikipedia $(p=0.000)$, e- book reader $(p=0.000)$, Facebook $(p=0.000)$. 
The instructors gave significantly higher score to the projector $(\mathrm{p}=0.000)$ and a slide show $(\mathrm{p}=0.000)$. There is no significant difference in the evaluation of the following ICT devices: computers $(\mathrm{p}=0.923)$, interactive whiteboard $(\mathrm{p}=$ $0.316)$, e- learning material $(\mathrm{p}=0.054)$, camera $(\mathrm{p}=0.189)$ webcam $(\mathrm{p}=0.111)$, Neptun education organization interface (Appendix, $4^{\text {th }}$ chart, $7^{\text {th }}$ question; $\left(28^{\text {th }}\right.$ question).

\section{Discussion}

The following is a summary of responses to $y$ the hypotheses that were created at the beginning of the paper based on the results of the questionnaire research. Statistical data tables of hypotheses are to be found in the Appendix.

H1 hypothesis: Teachers who work in higher education prefer ICT tools related to traditional educational mothodology in teaching, while the web 2.0 tools are relegated to the background.

Teachers use the computer, a projector and a slide show (ppt) the most often. The reason may be that they are confident in using these: in terms of preparedness both the projector and computer plus slide show reached the highest value. I did not find a significant generational difference. The electronic learning curriculum -regardless of generation- is used less and also the teachers are less prepared for its use. In my further research I would like to examine the question of causality: whether they use it less because they are not confident or prepared, or they are unprepared and therefore they use it rarely.

I consider this research hypothesis partially justified, but the hypothesis is not proven by sufficient evidence. The provision is reasonable due to lower number of elements of the instructor questionnaires, I consider additional tests necessary for the purpose of precise delimitation.

$\mathrm{H} 2$ hypothesis: The usefulness of different ICT tools is perceived as different from the student and teacher evaluations

Concerning the use of ICT tools in educational environments the first four places in each group are: computers, projectors, electronic curriculum and a slide (ppt). If the results are examined more thoroughly, then we can find differences. In students' case the computers, projectors, electronic teaching resources and the slide show (ppt) are the four highly rated tools. There are significant age differences too. In the case of instructors the ranking was the following: projector slide show, computer, electronic teaching curriculum. Age differences can also be found here. There were generational differences shown in the instructors' work 
in Wikipedia, webcam and e- learning curriculum evaluation. The group of over 55 yrs consider Wikipedia and Webcam more useful.

There are significant differences in perception of the usefulness of ICT tools in comparison of teachers' and students' evaluations. Students evaluated the following ICT devices higher: smartphone, tablet, Wikipedia, e- book reader, Facebook. The instructors gave higher evaluation in the case of two ICT devices: projector and slide show. This hypothesis has been prooved, further interpretation of results will be dealt with in the summary section of my paper.

$\mathrm{H} 3$ hypothesis: the low number of online courses is explained by the poor institutional, personal, pedagogical, objectional criteria. I got my answers on the basis of instructors' answers to the data relating to infrastructural and institutional factors. On the institutional ICT equipment and infrastructure, perception is not unified, but in half of the instructors' responses it perceived as incomplete, and only under $10 \%$ of the respondents believed it was high. Opinions on institutional support, access to training opportunities and the institution's management attitude towards ICT tools strongly divided the respondents .

I found connection between the evaluation of the instituions' ICT facilities and the opportunities to participate in the introduction of the usage of ICT tools. Among those who believe that their institution lacks ICT facilities, a higher proportion confesses that there is no opportunity to attend these lectures. In terms of personality factors, it can be said that the majority of teachers are more open to the use of online tools. However, only every third instructor can attend the forums on ICT methods or technical information. The most common didactic method was marked by $91 \%$ of people as the front-of-class tools (lecture, explanation), and most common pedagogical activities are the slide show presentation of the curriculum.

The hypothesis has been partially addressed, but due to its complexity, I can not prove all the elements. Further interpretation of the results will be dealt with in the next section .

\section{Conclusion}

The present study also shows that the higher education environment supports the integration of modern technology achievements in the educational environment, but there are still unresolved issues. Its highlighted aim was to demonstrate the importance of the strategic use of modern ICT tools in higher education and the development of education levels of participants in ICT skills. 
In many cases of higher education teachers it can be said that they have never been made to use more complex ICT tools and they cannot handle the digital devices. If the instructor is not prepared for the usage of the technical tools (ICT skills shortage) he/she will avoid its use in education due to his/her insecurity towards it (Pillman Kubinger, 2011). This means that in the survey, the computer, projector and slide show (ppt) is not only the most common, but also the tools used the most confidently. In other institutions of higher education there can also be a similar situation, and digitization is often limited to Power Point slide show of the trainers in their presentations (Kubinger-Pillman, 2011, p.50)

One of the most serious ICT competence of teachers in higher education is currently the slideshow -as I could summarize ironically. The spread of the multimedia applications is important, almost everyone uses images, pictures, two-thirds of my respondents use texts, video films. I did not find convincing evidence to establish that the younger teachers' ICT competencies would be higher than the older instructor peers'.

Teaching attitude may be the key issue in digital development of higher education. The instructors are optimistic and open minded about the web 2.0 regarding e-learning: three -quarters of the sample think that the new applications represent value in the field of education, and two thirds of them believe that the university should be sure to keep pace with technological development. More than eighty percent of the respondents think that the use of advanced tools are associated with the use of new teaching methods. More than half $(57 \%)$ of teachers surveyed think that there is no possibility to participate in lectures where ICT tools are used regularly.

Such presentations can be an important advantage where educators can learn about using different instruments and it can help them with making themselves use these lessons more often. Roughly two-thirds of the sample have not participated in any forums (including online), which would give the possibility to obtain information about the new ICT methods or techniques. They are not informed either about the new pedagogical tools and options (cooperative learning, project work, constructive pedagogy, collaboration) or organizational and methodological background.

The question is, if they get such a small proportion of educational help and do not take part in further training methodology or forums, how they will integrate into their daily teaching practice a high level of digital device usage. In the absence of institutional support and compelling circumstances they cannot be optimistic.

In the case of using the Web's 2.0 tools, the method should be based on a collaborative teaching management, which on one hand, gives high possibility to 
access ICT devices, on the other hand, it needs to be accompanied with a strong ICT user competencies (staff, students).

The majority of teachers lack better knowledge of modern pedagogical principles and methodological tools, especially if we look at the European Union expectations and standards (Kárpáti \& Hunya, 2009).

The pedagogical methodology is vety similar -regardless of age- in higher education: the frontal teaching dominates (lecture, explanation), the most common educational activity is the slideshow in the curriculum. The student information retrieval and processing, and communication device use patterns question the efficiency of methods. If teachers do not learn to speak the language of the netgeneration and apply this in education, the members of the younger generation will turn away from the formal education activity in increasing numbers.

Higher education teachers have the required infrastructure knowledge, but they do not have to translate it into the language of netgenereration. They need to develop new and advanced methodologies for their subjects with the help of their pupils (Prensky, 2001). From the statements referring to generation Z, instructors (over 80\%) agreed on two things: the visual stimuli are important for today's students (and there have a great influence on them); and they need stimulus environment.

More than $90 \%$ of the teachers in the sample attach importance to the two-way communication (and gives high evaluation for the agreement), almost $80 \%$ highlight the cooperative techniques in pedagogical methods, two-thirds highlight the project work. The question is what is actually meant by this, because the frontal didactic tools are applied by the majority of teachers in higher education. According to the responses the most common pedagogical activitiy is the projector presentation of the curriculum. According to the instructors, the most important skills of students should be the understanding and comprehension of texts that cannot be developed through frontal lectures only.

The literacy of texts and effective inqury in digital texts and in e-learning are important competences in online learning (Papp - Danka, 2014). Students also have a preference for collective, interactive problem solving tasks over the frontal education. Higher education needs teaching methodology and didactic reforms. Reform pedagogy does not reach the higher education system and its rigid and conservative tool system, so self- supporting and autonomous knowledge processes stay in the background.

The educational world of universities is a special agent: on one hand, the majority of academic teachers do not have pedagogical qualification, on the other hand, they are given a large autonomy in terms of training tools and methods. They are aware of the new expectations (results of teaching questionnaire show 
this), that are an important element of the competency-based education, but in practice the academic routine is still relevant, such as frontal teaching (lecture, explanation), which is based on classroom performance.

This is understandable in the absence of monitoring and control and appropriate feedback. Changing attitudes are needed: the "ivory tower" elitist higher education and its representatives must be moving with the times, into services and student-centered direction. The retention factor is due to the infelxibility of higher education sector and the conservative approaches. Implementation of the frontal teaching has changed, and today teachers use projector and slideshows instead of chalks. The student activity can be increased in classroom teaching, it can be creative- and critical thinking, can be developing tohether with discussion skills, and problem solving skills.

Higher education teachers' competence needs continuous improvement of ICT competencies in order to become more adaptable and open to the usage of new instruments. This -as the survey research has shown- cannot be provided by all of the institutions. It is worth thinking about the establishment of ICT and an institution elarning coordination group, which centrally supports teachers with academics methodological publications, with availability of materials, and with using thematic forums and expert consultation.

Serious institutional strategic development changes are needed that could build a bridge between competence levels and students' needs. The differences between digital natives and digital immigrants point out development paths, they are giving new opportunities that give reason for the reconsideration of the existing university education system. There is a complex picture with regard to how the institutions are equipped with the ICT tools and whether the teachers are supported by ICT trainers or training. This is likely to be investigated differently. Autonomous faculties, institutes from the aspect of education, show a very heterogeneous picture, according to the survey. This shows a lack of central coordination of university.

The national higher education experience does not give too many encouraging signs so far, the small number of e- learning courses, the ICT skills of teachers and the poor tool use show gaps if we look at the international comparisons. Instructors use certain online learning management programs (Neptune, Moodle) for organizing the classes, but the complex web 2.0 tool usage (blogs, social networking, video, audio sharing sites, social bookmarking, etc.) is not widespread in higher education. Most of the teachers cannot confidently use the institutionally imposed online framework (Neptune) either, not to mention the e-learning. 
I do not mean to say that the interest in Internet use and openness are age-related factors, Iwould merely point out that students in higher education have very different training and educational backgrounds, which may affect their demands. Slowly, teachers' attitudes towards online education are changing. ICT tools need to be built in teaching practice, online technology has to be geared to the needs of youngsers' needs and language too and also the education organization and the curriculum has to be adapted to the new requirements, including the teacher's role in re-evaluation (Olle et al., 2015)

For doing this, change is essential in attitudes of the institutions, the frontal teaching activities should be replaced with a more modern approach of education, that calls the teachers to account for the pedagogical efficiency (Olle, 2014). In this study the exact role of the institutions cannot be explored. We could not overlook the fact that the integration of ICT in educational institution level is time- and money-consuming. Daily use of ICT is increasingly common, however, its integration into education is not seamless (educational ICT tools gives a good overview of Forgó \& Antal, 2013).

Such a complex paradigm shift in the methodological area would take decades. I find it important to emphasize that the adaptation and implementation of activity-based teaching and learning methodologies in higher education can be effective in parallel with the rate of reduction of frontal teaching. Unless the teachers are foced by the institutions to think about the usage of information and educational tools, the IT infrastructure is developed, and teachers are provided by trainings, there is a little chance for change (Sari, 2009).

It is difficult to decide whether we have such provision in an unfavourable higher education like ours - my research has not been focusing on this issue. It is likely that only a radical reform of higher education will be able to resolve the problem.

\section{References}

Авоnyi-Tóth, A. (2010). A digitális kompetencia. Budapest: ELTE Informatikai Kar, Média- és Oktatásinformatikai Tanszék, Média Informatika és Technológia Csoport. Retrived from http://abonyita.inf.elte.hu/digkomp20100225.pdf\%20

Duga, Zs. (2013). Tudomány és a fiatalok kapcsolata. Pécs: Pécsi Tudományegyetem Közgazdaságtudományi Kar - Tudománykommunikáció a Z generációnak. Retrieved January 12, 2016 from http://www.zgeneracio.hu/tanulmanyok

Ferrari, A. (2013). DIGCOMP: A Framework for Developing and Understanding Digital Competence in Europe. Luxembourg: European Commission. Joint Research Centre. Retrived from http://ftp.jrc.es/EURdoc/JRC83167.pdf 
Forgó, S., \& AnTal, P. (2013). A pedagógus mesterség IKT alapjai. Eger: Líceum Kiadó. Retrived from http://p2014-26.palyazat.ektf.hu/public/uploads/17-a-pedagogusmesterseg-ikt-alapjai_55e9c795380f7.pdf

Kárpáti, A., \& Hunya, M. (2009). Kisérlet a tanárok IKT-kompetenciája közös európai referenciakeretének kialakitására - a U-Teacher projekt I. Budapest: Új Pedagógiai Szemle. Retrived December 2, 2015 from http://ofi.hu/karpati-andrea-hunya-marta-kiserlet-tanarok-ikt-kompetenciaja-kozos-europai-referenciakeretenek-0

Kelan, E., \& Lehnert, M. (2009). The millennial generation: Generation $Y$ and the opportunities for a globalised, networked educational system. Bath: Education Department, University of Bath. Retrieved from http://www.academia.edu/4335172/ The_millennial_generation_generation_y_and_the_opportunities_for_a_globalised_networked_educational_system

Komenczi, B. (2013). Elektronikus tanulási környezetek sajátosságai. In A. Benedek, \& E. Golnhofer, (Eds.), Tanulmányok a neveléstudomány köréböl (pp. 54-76). Budapest: MTA Pedagógiai Tudományos Bizottság. Retrived from http://old.ektf. hu/-kbert/2013_14_02/komenczi_etk_20131111.pdf

Kubinger-Pillmann, J. (2011). Digitális pedagógiai módszer és eszköztár alkalmazása a felsőoktatásban. Iskolakultúra, 2011(20), 48-59. Retrived from http://epa.oszk. hu/00000/00011/00160/pdf/iskolakultura_2011_12_048-059.pdf

Kulcsár, Z. (2009). Hálózati tanulás. Oktatás-Informatika, 1, 5-15. Retrieved from http://matchsz.inf.elte.hu/tt/docs/Kulcsar-Zsolt-Halozati-tanulas.pdf

Magyar, F. (2012). IKT technológiák és alkalmazásuk. Pécs: PTE Deák Ferenc Gyakorló Gimnázium és Általános Iskola. Retrieved from http://pedtamop412b.pte.hu/ files/tiny_mce/File/iktalap_mf.pdf

Molnár, B. (2011). Pedagógushallgatók internethasználata és internetalapú tanulási tevékenységei a Debreceni Egyetem Gyermeknevelési és Felnöttképzési Karán. Doktori disszertáció. Debrecen: Debreceni Egyetem Humán Tudományok Doktori Iskola. Retrieved from https://dea.lib.unideb.hu/dea/bitstream/handle/2437/118291/ Molnar_Balazs_Tezisek_magyarul-t.pdf?sequence $=8$ \&isAllowed $=\mathrm{y}$

Ollé, J. (2012). Digitális állampolgárság értelmezése és fejlesztési lehetöségei. Budapest: Oktatás-Informatika. Retrieved March 20, 2015 from Retrieved from http://www. oktatas-informatika.hu/2012/07/olle-janos-a-digitalis-allampolgarsag-ertelmezese-es-fejlesztesi-lehetosegei/

Ollé, J., Kocsis, Á., Molnár, E., Sablik, H., PÁpai, A., \& Faragó, B. (2015). Oktatástervezés, digitális tartalomfejlesztés. Eger: Líceum Kiadó.

PaIs, E. R. (2013). Alapvetések a $Z$ generáció tudomány-kommunikációjához. Pécs: Pécsi Tudományegyetem Müszaki és Informatikai Kar. Retrieved March 1, 2016 from http://www.zgeneracio.hu/tanulmanyok

Papp-Danka, A. (2013). Digitális bennszülött vagy digitális állampolgár? - Tanulók a digitális világban. In P. D. Levente (Ed.), Digitális állampolgárság az információs társadalomban (pp. 29-41). Budapest: ELTE Eötvös Kiadó. Retrieved from http:// www.eltereader.hu/media/2014/01/Digitalis_allampolgarsag_READER.pdf 
Papp-Danka, A. (2014). Az online tanulási környezettel támogatott oktatási formák tanulásmódszertanának vizsgálata. Budapest: ELTE Eötvös Kiadó. Retrieved from http://www.eltereader.hu/media/2015/01/Papp_Danka_A_Online_tanulasi_ READER.pdf

Prensky, M. (2001). Digitális bennszülöttek, digitális bevándorlók. On the Horizon, 9(5), 1-6. Retrieved from http://goliat.eik.bme.hu/-emese/gtk-mo/didaktika/ digital_kids.pdf

SÁRI, S. (2009). "A tanári módszertan problémái a strukturálisan változó andragógus-képzó felsöoktatási intézményekben”. Pécs: Pécsi Tudományegyetem Bölcsésztudományi Kar, Neveléstudományi Doktori Iskola. Retrieved from http://pea.lib.pte.hu/bitstream/handle/pea/14733/sari-szilvia-phd-2009.pdf?sequence $=1$ \&isAllowed $=y$

Sipos, A. M., Varga K., \& Egervári D. (2015). Net! Mindenekfelett? Pécs: Pécsi Tudományegyetem Felnőttképzési és Emberi Erőforrás Fejlesztési Kar, Könyvtár- és Információtudományi Intézet. Retrieved from http://mek.oszk.hu/14700/14787/14787.pdf

SzIJÁrtó, Z. (2013). "Forró témák" a Z-generáció kutatásban: Fogalmi keretek - módszertani megközelitések. Pécs: Pécsi Tudományegyetem Bölcsésztudományi Kar - Tudománykommunikáció a Z generációnak. Retrieved March 1, 2016 from http:// www.zgeneracio.hu/tanulmanyok

\section{Appendix - Statistical contexts}

Table 1: Major statistical correlations - Chi-squared test

\begin{tabular}{|c|c|c|c|c|c|c|c|c|c|c|c|}
\hline \multicolumn{3}{|c|}{ Question } & \multicolumn{2}{|c|}{$\begin{array}{l}\text { under } \\
35 \text { y.o. }\end{array}$} & \multicolumn{2}{|c|}{$\begin{array}{l}\text { between } \\
35-55 \text { y.o. }\end{array}$} & \multicolumn{2}{|c|}{$\begin{array}{c}\text { over } \\
55 \text { y.o. }\end{array}$} & \multirow[t]{2}{*}{ All } & \multirow{2}{*}{ 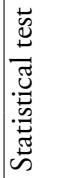 } & \multirow{2}{*}{ 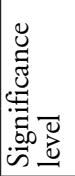 } \\
\hline & & & $\mathrm{N}$ & $\sum$ & $\mathrm{N}$ & $\Sigma$ & $\mathrm{N}$ & $\Sigma$ & & & \\
\hline 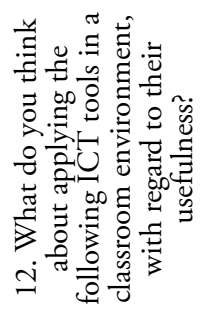 & 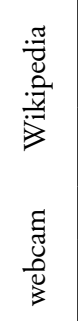 & $\begin{array}{l}\text { fully useful } \\
\text { not fully } \\
\text { useful } \\
\text { fully useful } \\
\text { not fully } \\
\text { useful }\end{array}$ & 31 & 32 & $\begin{array}{l}74 \\
15 \\
69\end{array}$ & 84 & $\begin{array}{r}8 \\
24\end{array}$ & 32 & 148 & 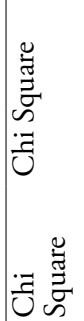 & 0,049 \\
\hline 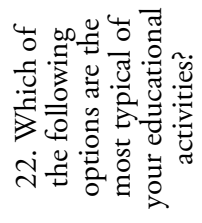 & 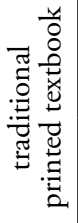 & $\begin{array}{l}\text { choosen by } \\
\text { not } \\
\text { choosen by }\end{array}$ & 14 & 32 & 47 & 84 & 10 & 32 & 148 & 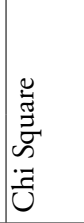 & 0,046 \\
\hline
\end{tabular}


Table 2: Major statistical correlations - Fisher's exact test

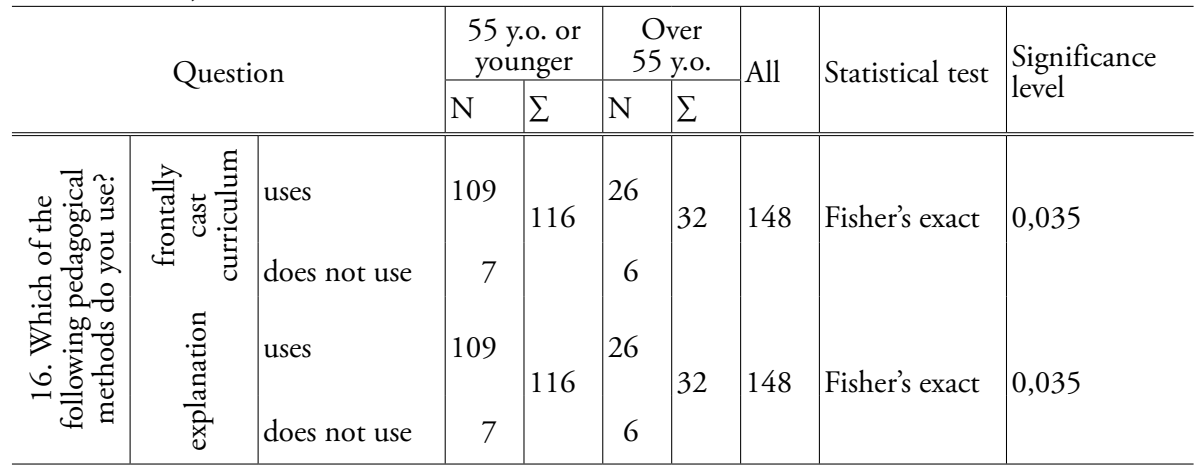

Table 3: Statistical correlations of questions 8 and 10

\begin{tabular}{|c|c|c|c|c|c|c|}
\hline & \multicolumn{2}{|c|}{$\begin{array}{l}\text { 10. Do you have the } \\
\text { opportunity to attend lectures } \\
\text { by others where } \\
\text { ICT tools are used regularly? }\end{array}$} & \multirow[t]{2}{*}{ All } & \multirow[t]{2}{*}{$\begin{array}{l}\text { Statistical } \\
\text { test }\end{array}$} & \multirow[t]{2}{*}{$\begin{array}{l}\text { Significance } \\
\text { level }\end{array}$} \\
\hline & & $\begin{array}{l}\text { Yes there } \\
\text { is }\end{array}$ & $\begin{array}{l}\text { no, is not } \\
\text { organized such }\end{array}$ & & & \\
\hline $\begin{array}{l}\text { 8. What is your } \\
\text { facility's equipment } \\
\text { with regard to ICT } \\
\text { tools? }\end{array}$ & $\begin{array}{l}\text { deficient } \\
\text { at least } \\
\text { adequate }\end{array}$ & 33 & 38 & 71 & Chi Square & $\mathrm{p}=0,015$ \\
\hline
\end{tabular}

Table 4: Statistical correlations of educational and student responses to the utility of the listed ICT factors

\begin{tabular}{|c|c|c|c|c|c|c|}
\hline \multirow[t]{3}{*}{ Question } & \multicolumn{2}{|c|}{ 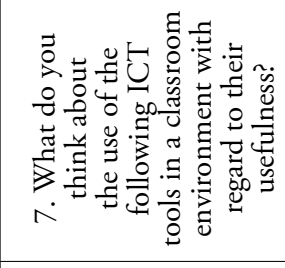 } & \multicolumn{2}{|c|}{ 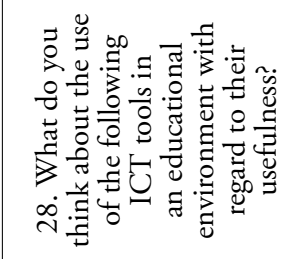 } & \multirow[t]{3}{*}{$\begin{array}{l}\text { Statistical } \\
\text { test }\end{array}$} & \multirow[t]{3}{*}{$\begin{array}{l}\text { Significance } \\
\text { level }\end{array}$} \\
\hline & \multicolumn{2}{|c|}{ instructor answers } & \multicolumn{2}{|c|}{ student answers } & & \\
\hline & $\mathrm{N}$ & Average & $\mathrm{N}$ & Average & & \\
\hline projector & 148 & 4,8 & 658 & 4,6 & $\begin{array}{l}\text { Mann- } \\
\text { Whitney }\end{array}$ & 0,000 \\
\hline slideshow (ppt) & 148 & 4,7 & 658 & 4,4 & $\begin{array}{l}\text { Mann- } \\
\text { Whitney }\end{array}$ & 0,000 \\
\hline
\end{tabular}




\begin{tabular}{|c|c|c|c|c|c|c|}
\hline \multirow[t]{3}{*}{ Question } & \multirow{2}{*}{\multicolumn{2}{|c|}{ 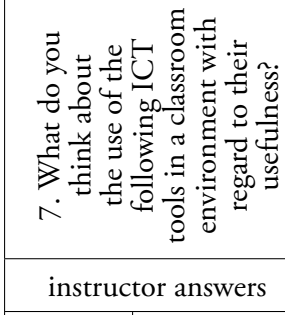 }} & \multirow{2}{*}{\multicolumn{2}{|c|}{ 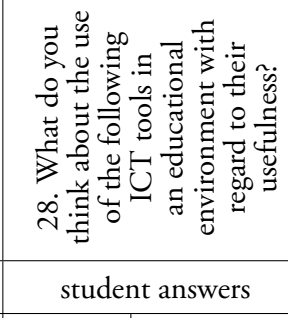 }} & \multirow[t]{3}{*}{$\begin{array}{l}\text { Statistical } \\
\text { test }\end{array}$} & \multirow[t]{3}{*}{$\begin{array}{l}\text { Significance } \\
\text { level }\end{array}$} \\
\hline & & & & & & \\
\hline & $\mathrm{N}$ & Average & $\mathrm{N}$ & Average & & \\
\hline computer & 148 & 4,7 & 658 & 4,7 & $\begin{array}{l}\text { Mann- } \\
\text { Whitney }\end{array}$ & 0,923 \\
\hline $\begin{array}{l}\text { electronic learning } \\
\text { materials }\end{array}$ & 148 & 4,5 & 658 & 4,4 & $\begin{array}{l}\text { Mann- } \\
\text { Whitney }\end{array}$ & 0,054 \\
\hline intercave table & 148 & 3,7 & 658 & 3,7 & $\begin{array}{l}\text { Mann- } \\
\text { Whitney }\end{array}$ & 0,316 \\
\hline $\begin{array}{l}\text { Neptun education } \\
\text { management } \\
\text { system }\end{array}$ & 148 & 3,6 & 658 & 3,4 & $\begin{array}{l}\text { Mann- } \\
\text { Whitney }\end{array}$ & 0,068 \\
\hline tablet & 148 & 3,5 & 658 & 3,9 & $\begin{array}{l}\text { Mann- } \\
\text { Whitney }\end{array}$ & 0,007 \\
\hline camera & 148 & 3,2 & 658 & 3,0 & $\begin{array}{l}\text { Mann- } \\
\text { Whitney }\end{array}$ & 0,189 \\
\hline webcam & 148 & 3,0 & 658 & 3,2 & $\begin{array}{l}\text { Mann- } \\
\text { Whitney }\end{array}$ & 0,111 \\
\hline Wikipedia & 148 & 2,9 & 658 & 3,5 & $\begin{array}{l}\text { Mann- } \\
\text { Whitney }\end{array}$ & 0,000 \\
\hline smart phone & 148 & 2,9 & 658 & 3,6 & $\begin{array}{l}\text { Mann- } \\
\text { Whitney }\end{array}$ & 0,000 \\
\hline e-book reader & 148 & 2,9 & 658 & 3,6 & $\begin{array}{l}\text { Mann- } \\
\text { Whitney }\end{array}$ & 0,000 \\
\hline Facebook & 148 & 2,5 & 658 & 2,9 & $\begin{array}{l}\text { Mann- } \\
\text { Whitney }\end{array}$ & 0,000 \\
\hline
\end{tabular}


Pankász Balázs ${ }^{2}$

Univerzitet u Pečuju, Mađaraska

\section{Onlajn obrazovna sredina i upotreba kompjuterskih tehnologija: anketa sprovedena nad predavačima}

Apstrakt: Uloga interneta i digitalnih tehnologija se ne moze poreći u 21. veku. Tehnološki razvoj zahteva brze promene u ovoj oblasti. Usled globalizacije, i inovacija u IT oblasti, učesnici u obrazovnom sistemu se suočavaju sa novim izazovima. Pojavljuju se nova pitanja i problemi koji zahtevaju rešavanje. Kako tehnološke potrebe i mogućnosti transformisu visoko obrazovanje? Da li je moguće koristiti web 2.0 aplikacije u obrazovanju? Kako i koliko uneti digitalne tehnologije u obrazovanje? Ova studija pokušava da otkrije stavove predavača i studenata o upotrebi web 2.0 i web 2.0 aplikacija u svrhe predavanja i učenja. Da li ove tehnologije mogu da se koriste u obrazovanju da doprinesu individualnoj i kolektivnoj izgradnji saznjanja? Naučne studije pokazuju da upotreba interneta među studentima nije homogena. Predavačima su potrebni novi kvaliteti i novi tip visokog obrazovanja. Ova anketa takođe pokušava da otkrije generacijske ralike u stavovima ka učenju i upotrebi interneta.

Ključne reči: visoko obrazovanje, web 2.0, teorije učenja

\footnotetext{
${ }^{2}$ Dr Pankász Balázs je docent na Univerzitetu u Pečuju (Mađarska), na Fakultetu za kulturološke nauke, obrazovanje i regionalni razvoj (pankasz.balazs@kpvk.pte.hu).
} 